\title{
Bioluminescence imaging of selenocysteine in vivo with a highly sensitive probe
}

Ling Zhang, ${ }^{\dagger}$ Yanfen Shi, ${ }^{\dagger}$ Zhijia Sheng, ${ }^{\dagger}$ Yiran Zhang, ${ }^{\dagger}$ Xiaoning Kai, ${ }^{\dagger}$ Minyong Li, ${ }^{*}, \S$ Xiaoxing Yin $^{*}, \uparrow$

$\dagger$ Jiangsu Key Laboratory of New Drug Research and Clinical Pharmacy, Jiangsu Center for the Collaboration and Innovation of Cancer Biotherapy, School of Pharmacy, Xuzhou Medical University, Xuzhou 221002, PR China.

$\S$ Department of Medicinal Chemistry, Key Laboratory of Chemical Biology, School of Pharmacy, Shandong University, Jinan, 250012, PR China.

Corresponding Authors

* E-mail address: yinxx@xzhmu.edu.cn

* E-mail address: mli@sdu.edu.cn. 
General information

Synthesis and Characterisation of compounds

Evidence of mechanism detection

Determination of the detection limit

Preparation of the test solution

Cell culture

MTT Assay

Statistical analyses

References

Scheme S1. Synthesis route for BF-1.

Figure S1. Time profile of BF-1 towards Sec.

Figure S2. Stability of BF-1 in Tris-HCl buffer.

Figure S3. Effects of $\mathrm{pH}$ on $\mathrm{BF}-1$ in Tris-HCl buffer.

Figure S4. Effects of $\mathrm{pH}$ on D-luciferin in Tris-HCl buffer.

Figure S5. The anti-interference ability of BF-1 to detect Sec in the presence of biothiols and selenocompounds.

Figure S6. Selectivity of BF-1 to various amino acids.

Figure S7. Selectivity of BF-1 to various metal ions.

Figure S8. Selectivity of BF-1 to various ions.

Figure S9. Selectivity of BF-1 to reactive oxygen species, reactive nitrogen species.

Figure S10. Selectivity of BF-1 to $(\mathrm{Sec})_{2}, \mathrm{DTT}, \mathrm{Na}_{2} \mathrm{SeO}_{3}, \mathrm{Na}_{2} \mathrm{Se}$ at different time.

Figure S11. Cell viability of MCF-7-luc cells in the presence of various concentrations of BF-1.

Figure S12. Cell viability of MCF-7-luc cells in the presence of BF-1 at various times.

Figure S13. Bioluminescence imaging of various concentrations of exogenous Sec in live MCF-7-luc cells.

Figure S14. Bioluminescence imaging of exogenous Sec at different times in live MCF-7-luc cells.

Figure S15. Representative bioluminescence images visualizing exogenous Sec in FVB-luc ${ }^{+}$mice.

Figure S16. Representative bioluminescence images visualizing $\mathrm{Na}_{2} \mathrm{SeO}_{3}$-induced Sec in FVB-luc ${ }^{+}$mice.

Figure S17. Representative bioluminescence images visualizing $\mathrm{Na}_{2} \mathrm{SeO}_{3}$-induced Sec in FVB-luc ${ }^{+}$mice.

Table S1. Total Photon Flux of the FVB-luc ${ }^{+}$mice.

Figure S18. Time-course bioluminescence imaging of $\mathrm{Na}_{2} \mathrm{SeO}_{3}$-induced $\mathrm{Sec}$ in FVB-luc ${ }^{+}$mice.

Figure S19. Time-course bioluminescence imaging of $\mathrm{Na}_{2} \mathrm{SeO}_{3}$-induced $\mathrm{Sec}$ in $\mathrm{FVB}-\mathrm{luc}^{+}$mice. 
Figure S20. Quantification of the total photon flux from the whole body area for the mice images in Figure 6, S18, S19.

Figure S21. Representative bioluminescence images of BF-1 in tumor-bearing mice.

Figure S22. Representative bioluminescence images of BF-1 in tumor-bearing mice.

Table S2. Total Photon Flux of the nude mice.

Figure S23. Time-course bioluminescence imaging of $\mathrm{Na}_{2} \mathrm{SeO}_{3}$-induced $\mathrm{Sec}$ in tumor-bearing mice.

Figure S24. Time-course bioluminescence imaging of $\mathrm{Na}_{2} \mathrm{SeO}_{3}$-induced $\mathrm{Sec}$ in tumor-bearing mice.

Figure S25. Time-course bioluminescence imaging of $\mathrm{Na}_{2} \mathrm{SeO}_{3}$-induced $\mathrm{Sec}$ in tumor-bearing mice.

Figure S26. Quantification of the total photon flux from the tumor area for the mice images in Figure S23, S24, S25.

Table S3. Summary of previous reported Sec probes.

Figure S27-33. NMR and HRMS spectrum of compounds. 
General Information. Thin layer chromatography (TLC) analysis was performed on silica gel 60 $\mathrm{F}_{254}$ plates $(250 \mu \mathrm{m})$ and column chromatography was conducted over silica gel (300-400 mesh). Visualization of the developed chromatogram was accomplished by a UV lamp.

Chemicals, materials and instruments. Unless noted otherwise, reagents and solvents were obtained from commercial suppliers and employed without further purification. Luciferase (Shenzhen Hiboled Century Biotechnology Co. Ltd., China). Dulbecco's modified Eagle's medium (DMEM), fetal bovine serum (FBS), penicillin $\left(100 \mu \mathrm{g} \mathrm{mL}^{-1}\right)$ and streptomycin $\left(100 \mu \mathrm{g} \mathrm{mL}^{-1}\right)$ were obtained from Life Technologies (CA, USA). Nuclear magnetic resonance (NMR) spectra were obtained by using a JEOL ECZ-400S operated at 400/100 MHz for ${ }^{1} \mathrm{H}$ NMR and ${ }^{13} \mathrm{C}$ NMR, respectively. High-resolution mass spectra (HRMS) were measured by using a mass spectrometer. The $\mathrm{pH}$ measurements were acquired with a Mettler-Toledo Delta $320 \mathrm{pH}$ meter. Absorbance in the MTT assay was recorded using a spectrophotometer (Thermo Fisher Scientific, Finland). All bioluminescence imaging was performed by using a Night OWL IILB 9983 small animal in vivo imaging system (Berthold Technologies, Germany).

\section{Synthesis and Characterisation of compounds}

Scheme S1. Synthesis Route for BF-1
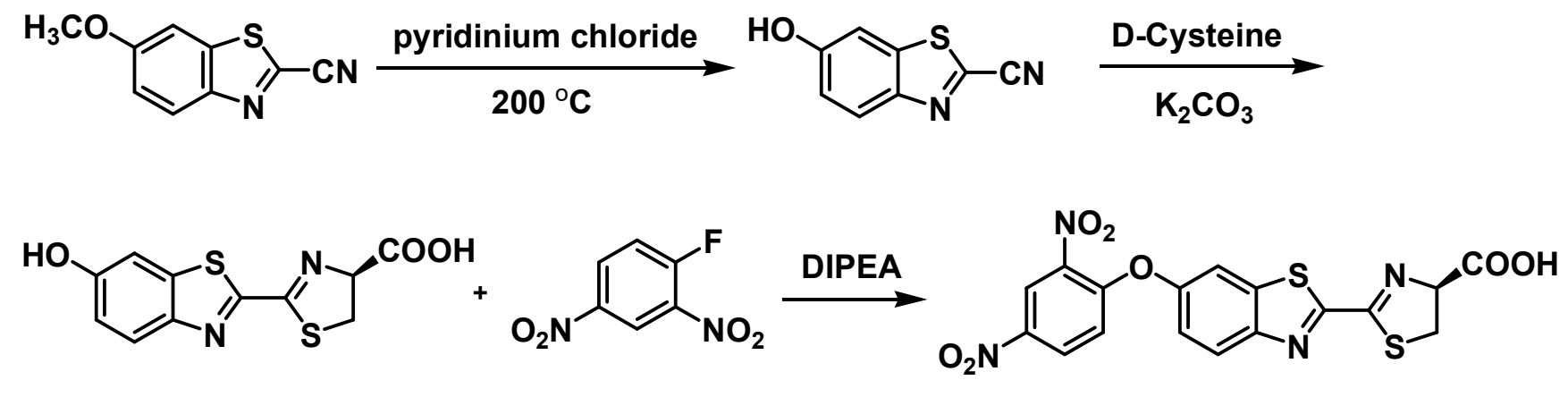

D-luciferin

BF-1

\section{Synthesis of D-luciferin.}

2-cyano-6-hydroxybenzothiazole and D-luciferin were synthesized according to the previous method. ${ }^{1}$ 2-cyano-6-hydroxybenzothiazole $(100 \mathrm{mg}, 0.57 \mathrm{mmol})$ was dissolved in the mixture solution of DCM (10 mL) and methanol $(15 \mathrm{~mL})$ under $\mathrm{N}_{2}$ atmosphere. A solution of D-Cysteine hydrochloride monohydrate (136 mg, $0.86 \mathrm{mmol})$ and $\mathrm{K}_{2} \mathrm{CO}_{3}(119 \mathrm{mg}, 0.86 \mathrm{mmol})$ in 1:1 DI $\mathrm{H}_{2} \mathrm{O}$ and methanol (3 $\mathrm{mL}$ ) was added to the above solution, and then the mixture was stirred at $0{ }^{\circ} \mathrm{C}$ for $10 \mathrm{~min}$. After evaporation of the organic solvent, the remaining aqueous solution was acidified to $\mathrm{pH} 2-3$ with $\mathrm{HCl}$ ( $1 \mathrm{M}$ ), forming a yellow precipitate. The crude product was purified by silica gel column chromatography (DCM: MeOH: $\mathrm{AcOH}, 10: 1: 1 \mathrm{v} / \mathrm{v} / \mathrm{v}$ ) to give a yellow solid (128 mg, yield: $80.0 \%$ ). 
TLC (silica, DCM: MeOH: AcOH, 5: $1: 1 \mathrm{v} / \mathrm{v} / \mathrm{v}): \mathrm{R}_{\mathrm{f}}=0.60 ;{ }^{1} \mathrm{H}$ NMR (400 MHz, $\left.\mathrm{CD}_{3} \mathrm{OD}\right): \delta 7.87-7.90$ (m, 1H), 7.32-7.33 (m, 1H), 7.04-7.7.07 (m, 1H), 5.38 (t, J = 9.6 Hz, 1H), 3.73-3.77 (m, 2H); HRMS $\left(\mathrm{ESI}^{+}\right): \quad(\mathrm{M}+\mathrm{H})^{+}$calcd. for $\mathrm{C}_{11} \mathrm{H}_{9} \mathrm{~N}_{2} \mathrm{O}_{3} \mathrm{~S}_{2}, \quad 281.0054$; found, 281.0049; $(\mathrm{M}+\mathrm{Na})^{+}$calcd. for $\mathrm{C}_{11} \mathrm{H}_{8} \mathrm{~N}_{2} \mathrm{O}_{3} \mathrm{NaS}_{2}$, 302.9874; found, 302.9868 .

Evidence of mechanism detection. BF-1 $(4.5 \mathrm{mg}, 0.01 \mathrm{mmol})$ was dissolved in DMSO $(1 \mathrm{~mL})$, and then the mixed solution of $(\mathrm{Sec})_{2}(3.4 \mathrm{mg}, 0.01 \mathrm{mmol})$ and DTT $(1.5 \mathrm{mg}, 0.01 \mathrm{mmol})$ in Tris- $\mathrm{HCl}$ buffer $\left(1 \mathrm{~mL}, 50.0 \mathrm{mM}, \mathrm{pH}=7.4, \mathrm{MgCl}_{2}=10 \mathrm{mM}\right)$ was added. After stirring at $37^{\circ} \mathrm{C}$ for $60 \mathrm{~min}$, the resultant mixture was extracted by EtOAc. The product was thereafter purified by column chromatography, and the spectra obtained by ${ }^{1} \mathrm{H}$ NMR and HRMS were consistent with those of D-luciferin, hence confirmation of the product as compound D-luciferin.

Determination of the detection limit. The detection limit was calculated based on previous method. ${ }^{2}$ The BL intensity of BF-1 without Sec was measured by 10 times and the standard deviation of blank measurement was determined. Then the probe solution was added with Sec of concentration from 0 to $20 \mu \mathrm{M}$. A linear regression curve was then achieved according to the BL intensity in the range of Sec from 0 to $20 \mu \mathrm{M}$. The detection limit was calculated with the following equation: Detection limit $=3 \sigma / \mathrm{k}$. Where $\sigma$ is the standard deviation of blank measurements, $\mathrm{k}$ is the slope between the BL intensity versus Sec concentrations.

\section{Preparation of the test solution}

(1) BF-1 stock solution preparation: BF-1 (4.5 mg, $0.01 \mathrm{mmol})$ was dissolved into DMSO (10 mL) to get $1.0 \mathrm{mM}$ stock solution.

(2) Sec stock solution preparation: Sec was generated in situ by mixing equal molar of (Sec) $)_{2}$ with DTT to get $1.0 \mathrm{mM}$ stock solution in DI $\mathrm{H}_{2} \mathrm{O}$, which was then diluted to $1.0 \mathrm{mM}$ and $100 \mu \mathrm{M}$ solution for general use.

(3) Cys (L-Cysteine) stock solution preparation: Cys (24.2 mg, $0.2 \mathrm{mmol}$ ) was dissolved into $\mathrm{DI}_{2} \mathrm{O}$ $(10 \mathrm{~mL})$ to get $20.0 \mathrm{mM}$ stock solution, which was then diluted to $1.0 \mathrm{mM}$ solution for general use.

(4) Hcy (Homocysteine) stock solution preparation: Hcy $(27.0 \mathrm{mg}, 0.2 \mathrm{mmol})$ was dissolved into DI $\mathrm{H}_{2} \mathrm{O}(10 \mathrm{~mL})$ to get $20.0 \mathrm{mM}$ stock solution, which was then diluted to $1.0 \mathrm{mM}$ solution for general use.

(5) GSH (Glutathione) stock solution preparation: GSH (61.5 mg, $0.2 \mathrm{mmol}$ ) was dissolved into DI $\mathrm{H}_{2} \mathrm{O}(10 \mathrm{~mL})$ to get $20.0 \mathrm{mM}$ stock solution, which was then diluted to $10 \mathrm{mM}$ solution for general use.

(6) $\mathrm{Na}_{2} \mathrm{~S}$ stock solution preparation: ${ }^{3} 5 \mathrm{mg}$ EDTA was dissolved in $10 \mathrm{~mL}$ DI $\mathrm{H}_{2} \mathrm{O}$ in a $25 \mathrm{~mL}$ Schlenk tube. The solution was purged vigorously with nitrogen for $15 \mathrm{~min}$. Then $48 \mathrm{mg}$ sodium sulfide 
$\left(\mathrm{Na}_{2} \mathrm{~S} \cdot 9 \mathrm{H}_{2} \mathrm{O}\right)$ was dissolved in the solution under nitrogen. The resulting solution was $20 \mathrm{mM} \mathrm{Na} 2 \mathrm{~S}$, which was then diluted to $1.0 \mathrm{mM}-100 \mu \mathrm{M}$ stock solution for general use.

(7) N-acetyl-L-cysteine (NAC) stock solution preparation: NAC (32.6 mg, $0.2 \mathrm{mmol})$ was dissolved into $\mathrm{DI} \mathrm{H}_{2} \mathrm{O}(10 \mathrm{~mL})$ to get $20.0 \mathrm{mM}$ stock solution, which was then diluted to $1.0 \mathrm{mM}$ and 100 $\mu \mathrm{M}$ solution for general use.

(8) Stock solutions of other biological analytes, including amino acids such as Ala, Glu, Trp, Met, Tyr, Leu, Val, Ser, Pro, Arg, Gly, Phe, His, Gln, Asn, Ile, Thr; metal salts such as $\mathrm{LiCl}, \mathrm{NaCl}, \mathrm{KCl}$, $\mathrm{MgCl}_{2}, \mathrm{AlCl}_{3}, \mathrm{Zn}\left(\mathrm{NO}_{3}\right)_{2}, \mathrm{Mn}\left(\mathrm{NO}_{3}\right)_{2}, \mathrm{Co}\left(\mathrm{NO}_{3}\right)_{2}, \mathrm{Cd}\left(\mathrm{NO}_{3}\right)_{2}, \mathrm{Ni}\left(\mathrm{NO}_{3}\right)_{2}, \mathrm{CaCl}_{2}, \mathrm{HgCl}_{2}, \mathrm{Cu}\left(\mathrm{NO}_{3}\right)_{2}$, $\mathrm{FeCl}_{2}, \mathrm{FeCl}_{3}, \mathrm{AgNO}_{3}$; anions such as $\mathrm{NaF}, \mathrm{NaCl}, \mathrm{KBr}, \mathrm{KI}, \mathrm{NaAcO}, \mathrm{NaHCO}_{3}, \mathrm{NaN}_{3}, \mathrm{NaNO}_{3}$, $\mathrm{Na}_{2} \mathrm{SO}_{4}, \mathrm{NaSCN}, \mathrm{Na}_{2} \mathrm{C}_{2} \mathrm{O}_{4}, \mathrm{Na}_{2} \mathrm{~S}_{2} \mathrm{O}_{7}, \mathrm{NaHSO}_{3}, \mathrm{KCN}, \mathrm{NaClO}, \mathrm{Na}_{2} \mathrm{HPO}_{4}$; reducing agent (DTT, $\mathrm{NADH}$, glucose, ascorbic acid, selenocompounds such as $\mathrm{Na}_{2} \mathrm{SeO}_{3}, \mathrm{Na}_{2} \mathrm{Se}$, Se-methylselenocysteine, selenocystine, selenomethionine; reactive oxygen species such as $\mathrm{H}_{2} \mathrm{O}_{2}, \cdot \mathrm{OCl}^{-}, \mathrm{O}_{2}^{-}, \cdot \mathrm{OH},{ }^{\mathrm{t}} \mathrm{BuOOH}$; reactive nitrogen species such as $\mathrm{NO}_{2}^{-}$, $\mathrm{NO}$, were prepared in DI $\mathrm{H}_{2} \mathrm{O}$.

(9) Superoxide radicals $\left(\mathrm{O}_{2}{ }^{-}\right)$were generated according to the previous reported method. ${ }^{4} \cdot \mathrm{OH}$ was generated by Fenton reaction between $\mathrm{Fe}^{\mathrm{II}}$ (EDTA) and $\mathrm{H}_{2} \mathrm{O}_{2}$ quantitively. ${ }^{5} \mathrm{NO}$ was generated in from of 3-(Aminopropyl)-1-hydroxy-3-isopropyl-2-oxo-1-triazene (NOC-5, $50 \mu \mathrm{mol} / \mathrm{mL}$ ). $\mathrm{NO}_{2}{ }^{-}$ was generated from $\mathrm{NaNO}_{2}$.

Cell culture. MCF-7-luc cells (luciferase expression cell line, Suzhou GenePharma Co., Ltd., China) were employed in this experiment. The MCF-7-luc cells were cultured in DMEM supple mented with $10 \%(\mathrm{v} / \mathrm{v}) \mathrm{FBS}$ and penicillin/streptomycin $\left(100 \mu \mathrm{g} \mathrm{mL}^{-1}\right)$ at $37{ }^{\circ} \mathrm{C}$ under a humidified atmosphere with $5 \% \mathrm{CO}_{2}$. The cells were allowed to grow to $80 \%$ confluence before harvesting and were transferred to black 96 -well plates $\left(5 \times 10^{5}\right.$ cells per well).

MTT assay. The in vitro cytotoxicity of BF-1 were measured using standard MTT assay (Sigma-Aldrich). MCF-7 cells were seeded into 96-well plates at a density of 50,000 cells/well and then maintained at $37{ }^{\circ} \mathrm{C}$ in a $5 \% \mathrm{CO}_{2}$ incubator. The cells were incubated with varying concentrations of BF-1 for $0 \mathrm{~h}, 6 \mathrm{~h}, 12 \mathrm{~h}, 18 \mathrm{~h}$, and $24 \mathrm{~h}$, respectively. Cells in culture medium without BF-1 were used as control group. After the incubation time, $20 \mu \mathrm{L}$ of MTT dye (3-[4, 5-dimethylthiazol-2-yl]-2, 5-diphenyl tetrazolium bromide, $5 \mathrm{mg} / \mathrm{ml}$ in phosphate buffered saline), was added to each well, and incubated for an additional $4 \mathrm{~h}$ at $37^{\circ} \mathrm{C}$. Then, the remaining MTT solution was removed, and $150 \mu \mathrm{L}$ of DMSO was added to each well to dissolve the formazan crystals. The plate was shaken for $10 \mathrm{~min}$ and the absorbance was measured at $570 \mathrm{~nm}$ on a spectrophotometer. Each sample was performed in triplicate, and the entire experiment was repeated three times. The cell viability of BF-1 $(0 \mu \mathrm{M}, 5 \mu \mathrm{M}, 10 \mu \mathrm{M}, 20 \mu \mathrm{M}, 50 \mu \mathrm{M}, 100 \mu \mathrm{M})$ at $0 \mathrm{~h}, 6 \mathrm{~h}, 12 \mathrm{~h}, 18 \mathrm{~h}$, and $24 \mathrm{~h}$, further demonstrated that the BF-1 is of low toxicity to cultured MCF-7 cells. 
Statistical analyses. All statistical analyses were performed using SPSS software, version 16.0 (SPSS Inc., Chicago, IL, USA). Values are reported as the mean \pm SD (standard deviation of the mean). The data were analyzed with one-way analysis of variance (ANOVA). Statistical significance was set at $p<0.05$.

\section{References}

(1) McCutcheon, D. C.; Paley, M. A.; Steinhardt, R. C.; Prescher, J. A. Expedient synthesis of electronically modified luciferins for bioluminescence imaging. J Am Chem Soc. 2012, 9, 134, 7604-7607.

(2) Joshi, B. P.; Park, J.; Lee, W. I.; Lee, K. Ratiometric and turn-on monitoring for heavy and transition metal ions in aqueous solution with a fluorescent peptide sensor. Talanta. 2009, 78, 903-909. (3) Qian, Y.; Zhang, L.; Ding, S.; Deng, X.; He, C.; Zheng, X. E.; Zhu, H. L.; Zhao, J. A fluorescent probe for rapid detection of hydrogen sulfide in blood plasma and brain tissues in mice. Chem. Sci. 2012, 3, 2920-2923.

(4) Arudi, R.; Allen, A.; Bielski, B. Some observations on the chemistry of $\mathrm{KO}_{2}-\mathrm{DMSO}$ solutions. FEBS. Lett. 1981, 135, 265-267.

(5) Halliwell, B.; Gutteridge, J. M. Oxygen free radicals and iron in relation to biology and medicine: some problems and concepts. Arch. Biochem. Biophys. 1986, 246, 501-514.

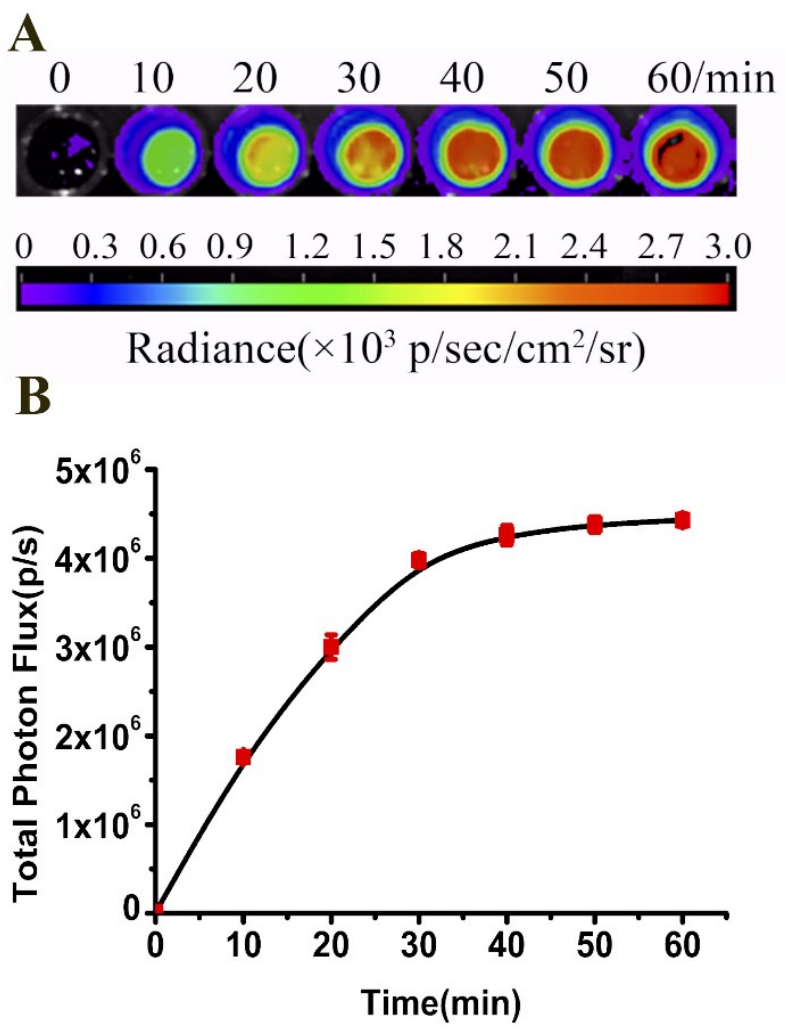

Figure S1. (A) The bioluminescence imaging of BF-1 $(10 \mu \mathrm{M})$ with Sec $(100 \mu \mathrm{M})$ in Tris-HCl buffer $(50 \mathrm{mM}$, $\mathrm{MgCl}_{2}=10 \mathrm{mM}, \mathrm{pH}=7.4,1 \% \mathrm{DMSO}$ ) at $37^{\circ} \mathrm{C}$ for $0,10,20,30,40,50$ and $60 \mathrm{~min}$. (B) Time-dependent total 
photon flux (photon/s) of BF-1 $(10 \mu \mathrm{M})$ with Sec $(100 \mu \mathrm{M})$ in Tris-HCl buffer. Luciferase (final concentration, $2 \mu \mathrm{g}$ $/ \mathrm{mL})$ and ATP $(2 \mathrm{mM}, 50 \mu \mathrm{L})$ were added after the incubation for $30 \mathrm{~min}$ at $37^{\circ} \mathrm{C}$.
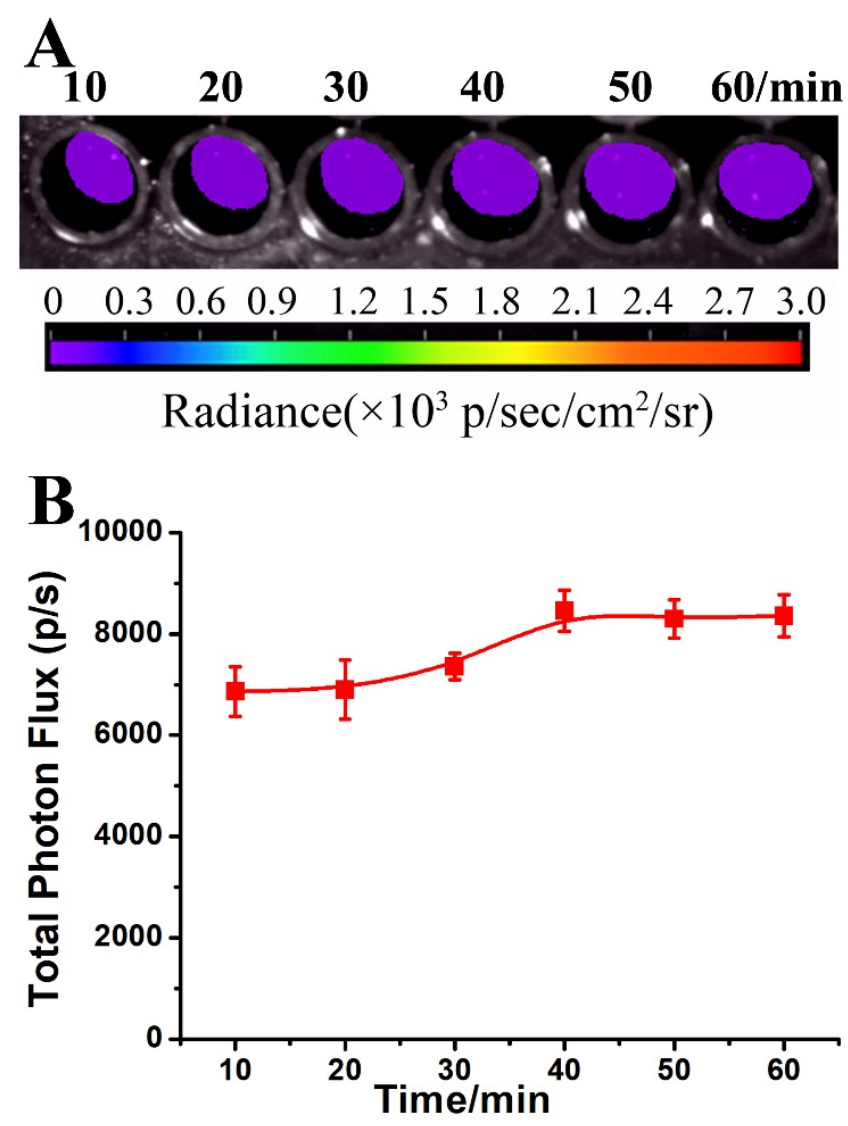

Figure S2. (A) Bioluminescence imaging of BF-1 $(10 \mu \mathrm{M})$ alone in Tris- $\mathrm{HCl}$ buffer $\left(50 \mathrm{mM}, \mathrm{MgCl}_{2}=10 \mathrm{mM}, \mathrm{pH}=\right.$ 7.4, 1\% DMSO) for 10, 20, 30, 40, 50 and 60 min. (B) Quantification of the total photon flux (photon/s) of BF-1 alone. Luciferase (final concentration, $2 \mu \mathrm{g} / \mathrm{mL})$ and ATP $(2 \mathrm{mM}, 50 \mu \mathrm{L}$ ) were added after the incubation for 10, 20, $30,40,50$ and $60 \mathrm{~min}$ at $37^{\circ} \mathrm{C}$. 


\section{A}

4.0 4.5 5.0 5.5 6.0 6.5 7.0 7.4 7.5 8.0 8.5 9.0

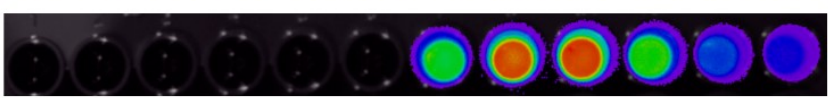

$\begin{array}{llllllllllll}0 & 0.3 & 0.6 & 0.9 & 1.2 & 1.5 & 1.8 & 2.1 & 2.4 & 2.7 & 3.0\end{array}$

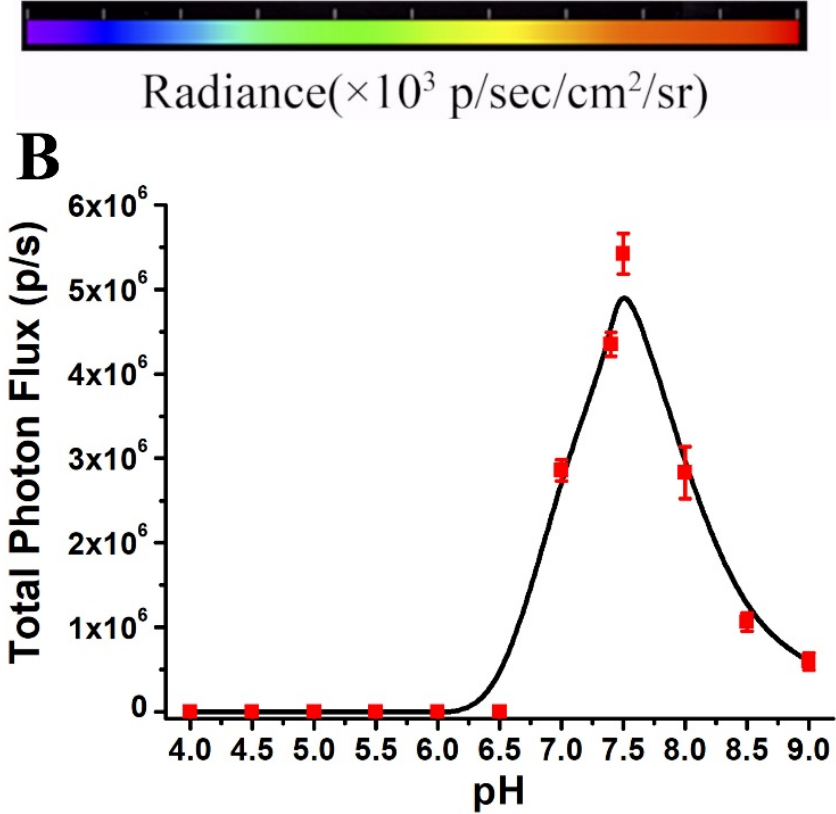

Figure S3. (A) The bioluminescence imaging of BF-1 $(10 \mu \mathrm{M})$ with Sec $(100 \mu \mathrm{M})$ in Tris- $\mathrm{HCl}$ buffer $(50 \mathrm{mM}$, $\left.\mathrm{MgCl}_{2}=10 \mathrm{mM}, 1 \% \mathrm{DMSO}, \mathrm{pH}=4.0,4.5,5.0,5.5,6.0,6.5,7.0,7.4,7.5,8.0,8.5,9.0\right)$ at $37{ }^{\circ} \mathrm{C}$ for $30 \mathrm{~min}$. (B) $\mathrm{pH}-d e p e n d e n t$ total photon flux (photon/s) of BF-1 $(10 \mu \mathrm{M})$ with Sec $(100 \mu \mathrm{M})$ in Tris-HCl buffer. Luciferase (final concentration, $2 \mu \mathrm{g} / \mathrm{mL})$ and ATP $(2 \mathrm{mM}, 50 \mu \mathrm{L})$ were added after the incubation for $30 \mathrm{~min}$ at $37^{\circ} \mathrm{C}$.

\section{A}

4.0 4.5 5.0 5.5 6.0 6.5 7.0 7.4 7.5 8.0 8.5 9.0
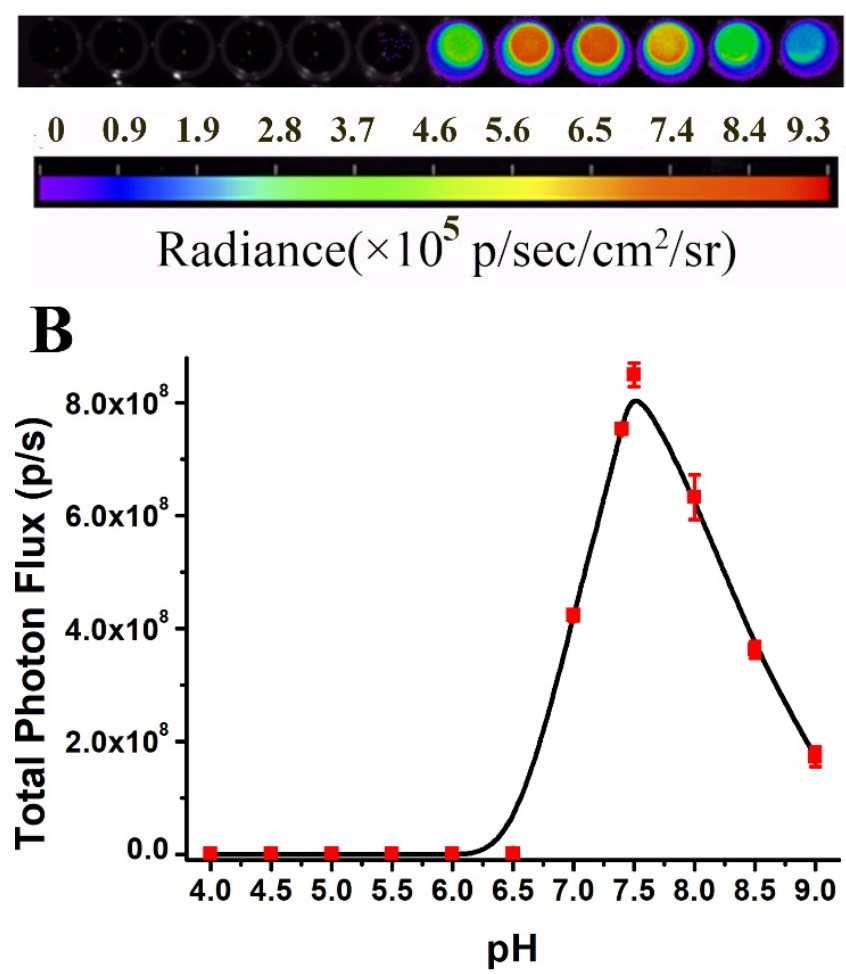

Figure S4. (A) The bioluminescence imaging of D-luciferin $(10 \mu \mathrm{M})$ in Tris- $\mathrm{HCl}$ buffer $\left(50 \mathrm{mM}, \mathrm{MgCl}_{2}=10 \mathrm{mM}\right.$, $1 \%$ DMSO, $\mathrm{pH}=4.0,4.5,5.0,5.5,6.0,6.5,7.0,7.4,7.5,8.0,8.5,9.0$ ) at $37{ }^{\circ} \mathrm{C}$ for $30 \mathrm{~min}$. (B) $\mathrm{pH}$-dependent total 
photon flux (photon/s) of D-luciferin $(10 \mu \mathrm{M})$ in Tris-HCl buffer. Luciferase (final concentration, $2 \mu \mathrm{g} / \mathrm{mL}$ ) and ATP $(2 \mathrm{mM}, 50 \mu \mathrm{L})$ were added after $30 \mathrm{~min}$ at $37^{\circ} \mathrm{C}$.
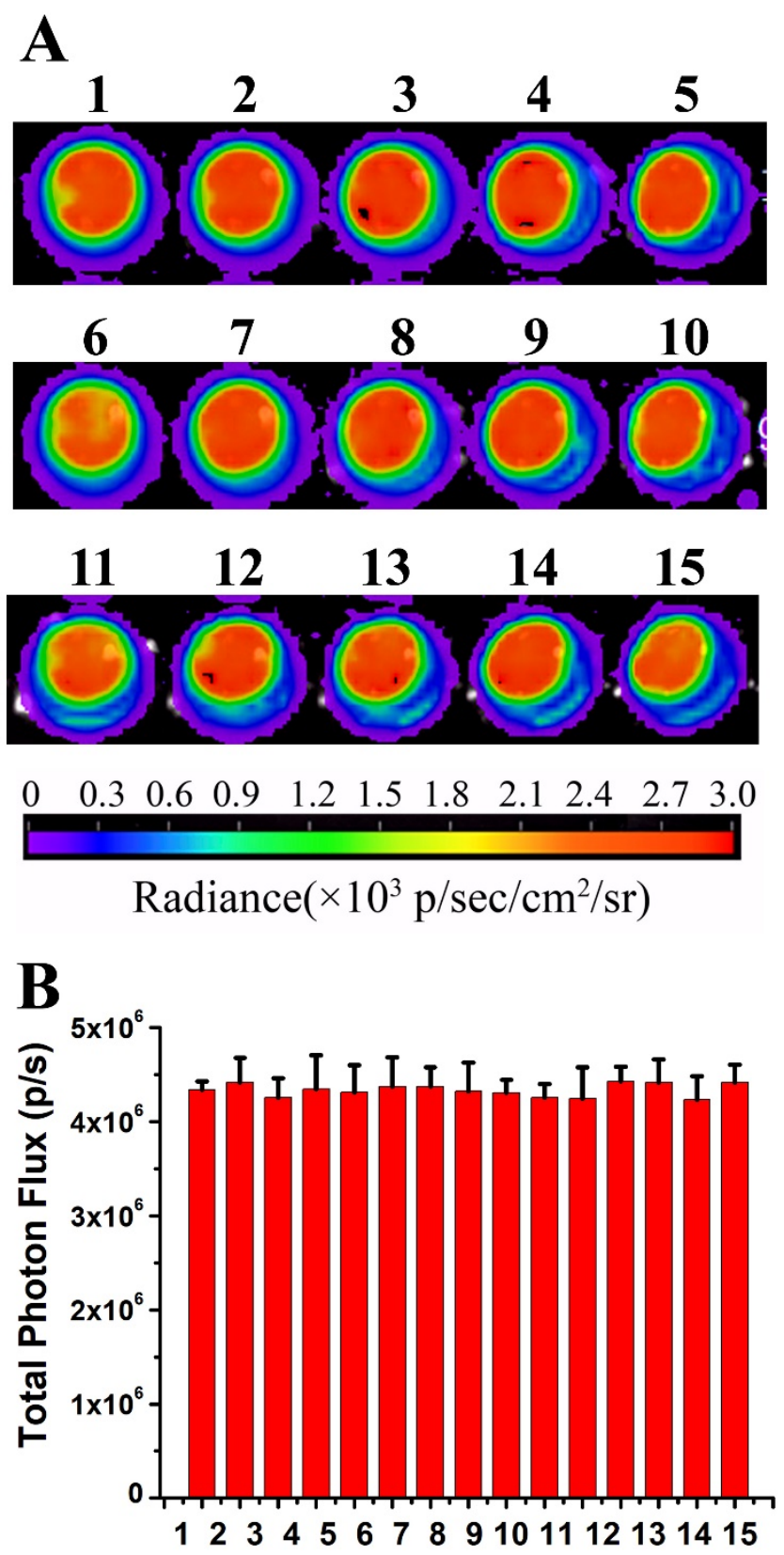

Figure S5. (A) Bioluminescence imaging of BF-1 $(10 \mu \mathrm{M})$ with various biothiols and selenocompounds in the presence of Sec $(100 \mu \mathrm{M})$ in Tris-HCl buffer $\left(50 \mathrm{mM}, \mathrm{MgCl}_{2}=10 \mathrm{mM}, \mathrm{pH}=7.4,1 \% \mathrm{DMSO}\right)$. 1. Sec $(100 \mu \mathrm{M}) ; 2$. GSH $(10 \mathrm{mM})+\operatorname{Sec}(100 \mu \mathrm{M}) ; 3$. Cys $(1 \mathrm{mM})+\operatorname{Sec}(100 \mu \mathrm{M}) ; 4$. Hcy $(1 \mathrm{mM})+\operatorname{Sec}(100 \mu \mathrm{M}) ; 5 . \mathrm{Na}_{2} \mathrm{~S}(100 \mu \mathrm{M})+$ $\operatorname{Sec}(100 \mu \mathrm{M}) ; 6$. GPx $(50 \mu \mathrm{M})+\operatorname{Sec}(100 \mu \mathrm{M}) ; 7$. Trx $(50 \mu \mathrm{M})+\operatorname{Sec}(100 \mu \mathrm{M}) ; 8$. S $8(500 \mu \mathrm{M})+\operatorname{Sec}(100 \mu \mathrm{M}) ; 9$. NAC $(100 \mu \mathrm{M})+\operatorname{Sec}(100 \mu \mathrm{M}) ; 10$. GSSG $(1 \mathrm{mM})+\operatorname{Sec}(100 \mu \mathrm{M}) ; 11 . \mathrm{Na}_{2} \mathrm{SeO}_{3}(100 \mu \mathrm{M})+\operatorname{Sec}(100 \mu \mathrm{M}) ; 12$. $\mathrm{Na}_{2} \mathrm{Se}(100 \mu \mathrm{M})+\operatorname{Sec}(100 \mu \mathrm{M}) ; 13$. Se-methylselenocysteine $(100 \mu \mathrm{M})+\operatorname{Sec}(100 \mu \mathrm{M}) ; 14$. selenocystine $(100 \mu \mathrm{M})$ + Sec $(100 \mu \mathrm{M})$; 15. Selenomethionine $(100 \mu \mathrm{M})+\operatorname{Sec}(100 \mu \mathrm{M})$. (B) Quantification of the total photon flux (photon/s) of BF-1 with various biothiols and selenocompounds in the presence of Sec $(100 \mu \mathrm{M})$. Luciferase (final concentration, $2 \mu \mathrm{g} / \mathrm{mL})$ and ATP $(2 \mathrm{mM}, 50 \mu \mathrm{L})$ were added after incubation for $30 \mathrm{~min}$ at $37^{\circ} \mathrm{C}$. 
A
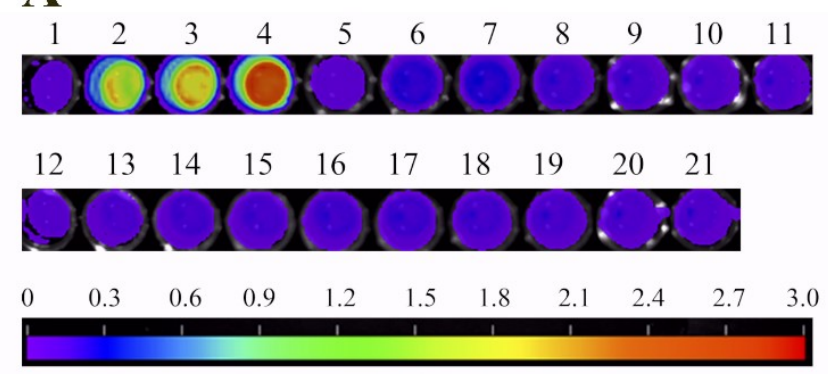

B

Radiance $\left(\times 10^{3} \mathrm{p} / \mathrm{sec} / \mathrm{cm}^{2} / \mathrm{sr}\right)$

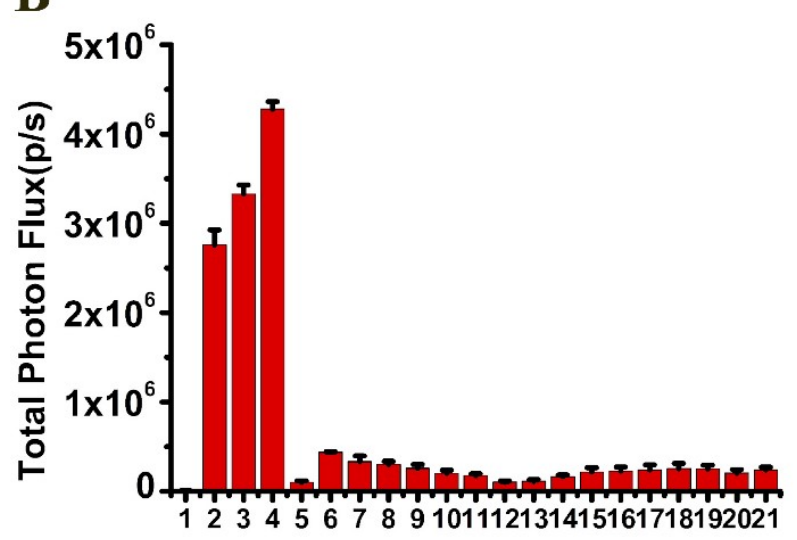

Figure S6. (A) Bioluminescence imaging of the selectivity of BF-1 $(10 \mu \mathrm{M})$ towards Sec, and various amino acids (1 $\mathrm{mM})$ in Tris-HCl buffer (50 mM, $\left.\mathrm{MgCl}_{2}=10 \mathrm{mM}, \mathrm{pH}=7.4,1 \% \mathrm{DMSO}\right)$. 1. Blank; 2. Sec (20 $\left.\mu \mathrm{M}\right)$; 3. Sec $(40 \mu \mathrm{M})$;

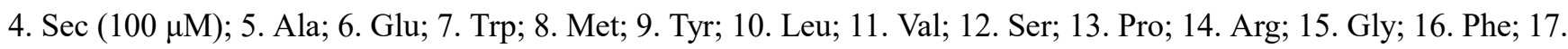
His; 18. Gln; 19. Asn; 20. Ile; 21. Thr. (B) Quantification of the total photon flux (photon/s) of BF-1 with Sec, and various amino acids. Luciferase (final concentration, $2 \mu \mathrm{g} / \mathrm{mL})$ and ATP $(2 \mathrm{mM}, 50 \mu \mathrm{L})$ were added after the incubation for $30 \mathrm{~min}$ at $37^{\circ} \mathrm{C}$.
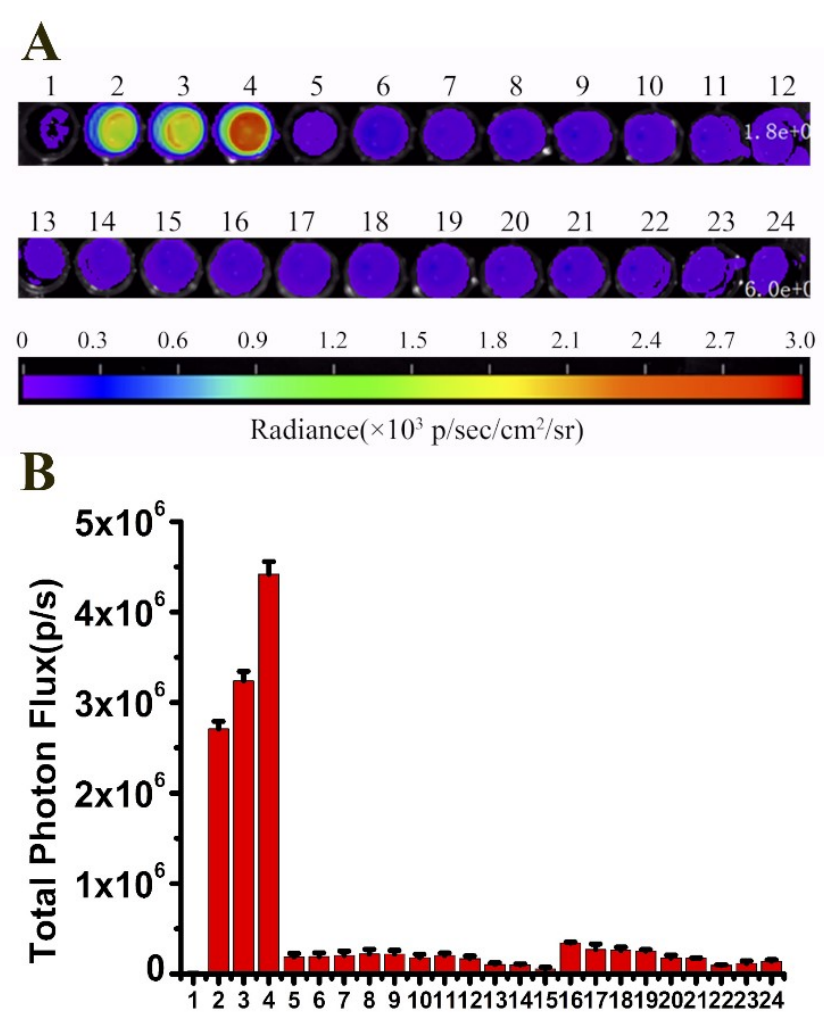

Figure S7. (A) Bioluminescence imaging of the selectivity of BF-1 $(10 \mu \mathrm{M})$ towards Sec, and various metal ions (1 
$\mathrm{mM})$ and other agent $(1 \mathrm{mM})$ in Tris- $\mathrm{HCl}$ buffer $\left(50 \mathrm{mM}, \mathrm{MgCl}_{2}=10 \mathrm{mM}, \mathrm{pH}=7.4,1 \% \mathrm{DMSO}\right)$. 1. Blank; 2. Sec $(20 \mu \mathrm{M})$; 3. Sec $(40 \mu \mathrm{M})$; 4. Sec $(100 \mu \mathrm{M}) ; 5 . \mathrm{Li}^{+} ; 6 . \mathrm{Na}^{+} ; 7 . \mathrm{K}^{+} ; 8 . \mathrm{Mg}^{2+} ; 9 . \mathrm{Al}^{3+} ; 10 . \mathrm{Zn}^{2+} ; 11 . \mathrm{Mn}^{2+} ; 12 . \mathrm{Co}^{2+} ; 13$. $\mathrm{Cd}^{2+} ; 14 . \mathrm{Ni}^{2+} ; 15 . \mathrm{Ca}^{2+} ; 16 . \mathrm{Hg}^{2+} ; 1$ 17. $\mathrm{Cu}^{2+} ; 18 . \mathrm{Fe}^{2+} ; 19 . \mathrm{Fe}^{3+} ; 20 . \mathrm{Ag}^{+} ; 21 . \mathrm{DTT} ; 22 . \mathrm{NADH} ; 23$. glucose; 24. ascorbic acid. (B) Quantification of the total photon flux (photon/s) of BF-1 with Sec, and various metal ions (1 mM) and other agent. Luciferase (final concentration, $2 \mu \mathrm{g} / \mathrm{mL})$ and ATP $(2 \mathrm{mM}, 50 \mu \mathrm{L})$ were added after the incubation for $30 \mathrm{~min}$ at $37^{\circ} \mathrm{C}$.

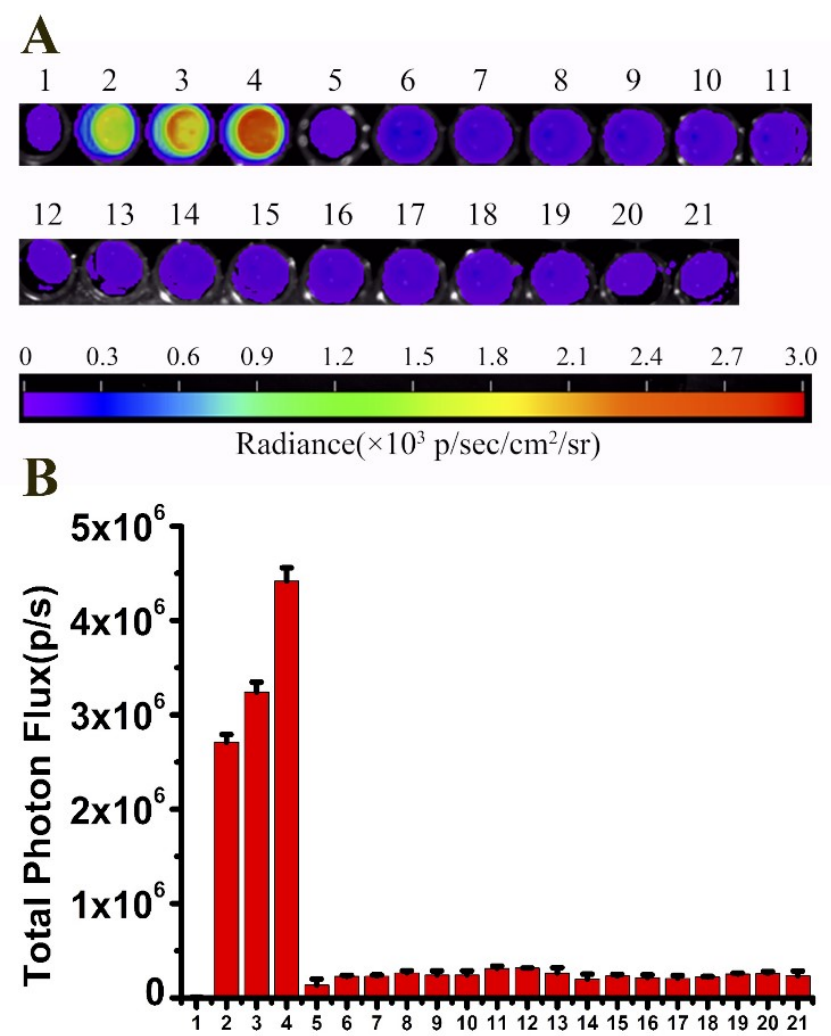

Figure S8. (A) Bioluminescence imaging of the selectivity of BF-1 (10 $\mu \mathrm{M})$ towards Sec, and various ions (1 mM) in Tris- $\mathrm{HCl}$ buffer (50 mM, $\mathrm{MgCl}_{2}=10 \mathrm{mM}, \mathrm{pH}=7.4,1 \%$ DMSO). 1. Blank; 2. Sec (20 $\left.\mu \mathrm{M}\right)$; 3. Sec $(40 \mu \mathrm{M})$; 4. Sec $(100 \mu \mathrm{M}) ; 5 . \mathrm{F}^{-} ; 6 . \mathrm{Cl}^{-} ; 7 . \mathrm{Br}^{-} ; 8 . \mathrm{I}^{-} ; 9 . \mathrm{AcO}^{-} ; 10 . \mathrm{HCO}_{3}^{-} ; 11 . \mathrm{N}_{3}^{-} ; 12 . \mathrm{NO}_{3}^{-} ; 13 . \mathrm{SO}_{4^{2-}} ; 14 . \mathrm{S}_{2} \mathrm{O}_{3}{ }^{2-} ; 15 . \mathrm{SCN}^{-} ; 16$. $\mathrm{C}_{2} \mathrm{O}_{4}{ }^{2-} ; 17 . \mathrm{S}_{2} \mathrm{O}_{7}{ }^{2-} ; 18 . \mathrm{HSO}_{3}{ }^{-} ; 19 . \mathrm{CN}^{-} ; 20 . \mathrm{ClO}^{-} ; 21 . \mathrm{HPO}_{4}{ }^{2-}$. (B) Quantification of the total photon flux (photon/s) of BF-1 with Sec, and various ions. Luciferase (final concentration, $2 \mu \mathrm{g} / \mathrm{mL})$ and ATP $(2 \mathrm{mM}, 50 \mu \mathrm{L}$ ) were added after the incubation for $30 \mathrm{~min}$ at $37^{\circ} \mathrm{C}$. 


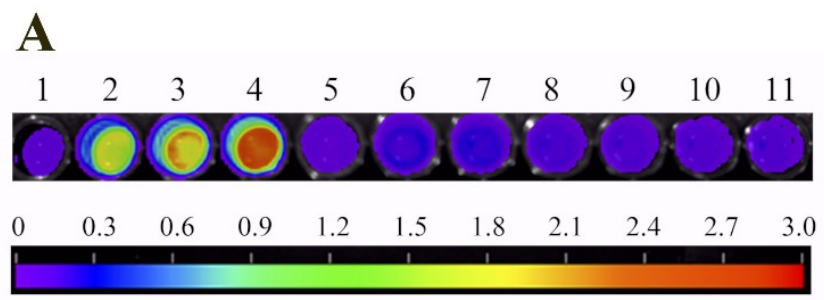

Radiance $\left(\times 10^{3} \mathrm{p} / \mathrm{sec} / \mathrm{cm}^{2} / \mathrm{sr}\right)$

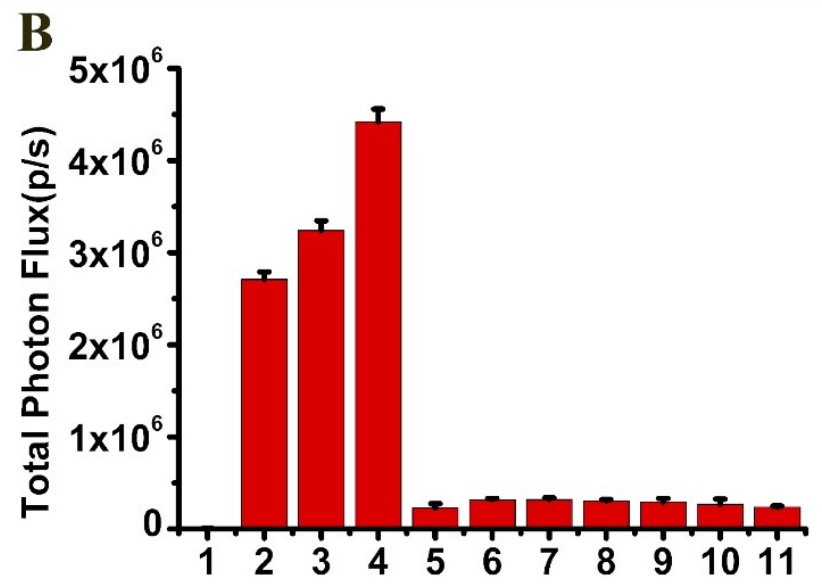

Figure S9. (A) Bioluminescence imaging of the selectivity of BF-1 $(10 \mu \mathrm{M})$ towards Sec, and reactive oxygen species, reactive nitrogen species $(1 \mathrm{mM})$ in Tris- $\mathrm{HCl}$ buffer $\left(50 \mathrm{mM}, \mathrm{MgCl}_{2}=10 \mathrm{mM}, \mathrm{pH}=7.4,1 \% \mathrm{DMSO}\right) .1$.

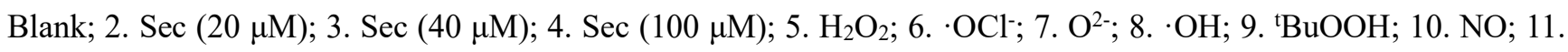
$\mathrm{NO}_{2}^{-}$. (B) Quantification of the total photon flux (photon/s) of BF-1 with Sec, and various reactive oxygen species, reactive nitrogen species $(1 \mathrm{mM})$. Luciferase (final concentration, $2 \mu \mathrm{g} / \mathrm{mL})$ and ATP $(2 \mathrm{mM}, 50 \mu \mathrm{L})$ were added after the incubation for $30 \mathrm{~min}$ at $37^{\circ} \mathrm{C}$.

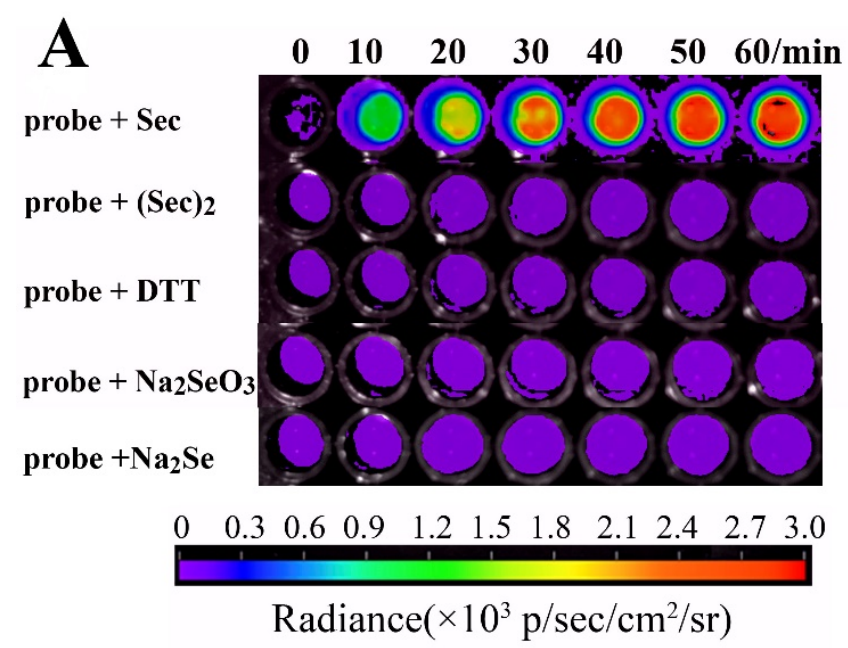




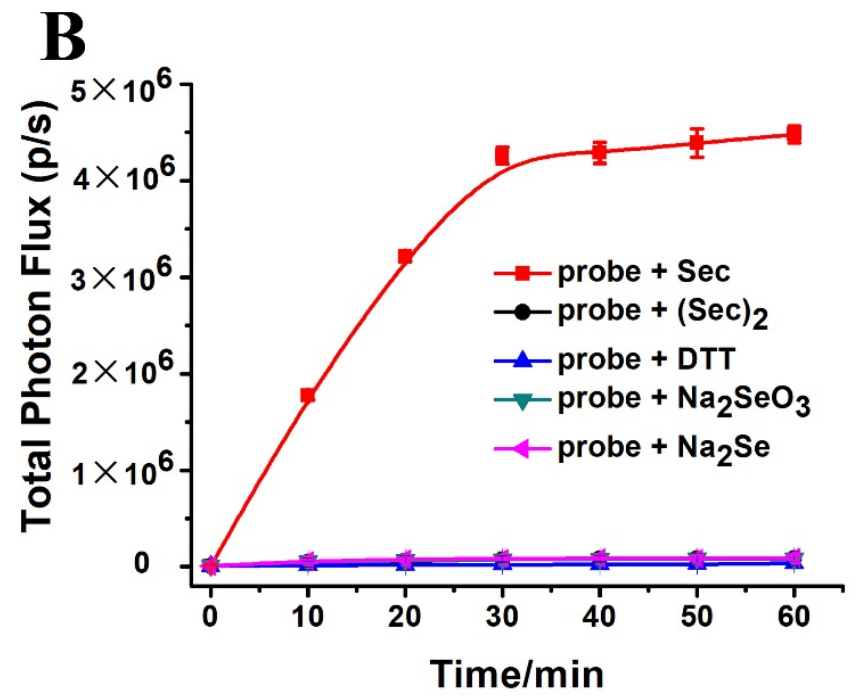

Figure S10. (A) The bioluminescence imaging of BF-1 $(10 \mu \mathrm{M})+\operatorname{Sec}(100 \mu \mathrm{M})$, BF-1 $(10 \mu \mathrm{M})+(\mathrm{Sec})_{2}(100 \mu \mathrm{M})$, BF-1 $(10 \mu \mathrm{M})+$ DTT $(100 \mu \mathrm{M}), \mathrm{BF}-1(10 \mu \mathrm{M})+\mathrm{Na}_{2} \mathrm{SeO}_{3}(100 \mu \mathrm{M}), \mathrm{BF}-1(10 \mu \mathrm{M})+\mathrm{Na}_{2} \mathrm{Se}(100 \mu \mathrm{M})$ in Tris-HCl buffer $\left(50 \mathrm{mM}, \mathrm{MgCl}_{2}=10 \mathrm{mM}, \mathrm{pH}=7.4,1 \% \mathrm{DMSO}\right)$ at $37{ }^{\circ} \mathrm{C}$ for 0, 10, 20, 30, 40, 50 and $60 \mathrm{~min}$. (B) Time-dependent total photon flux (photon/s) of BF-1 $(10 \mu \mathrm{M})+\operatorname{Sec}(100 \mu \mathrm{M})$, BF-1 $(10 \mu \mathrm{M})+(\mathrm{Sec})_{2}(100 \mu \mathrm{M})$, BF-1 $(10 \mu \mathrm{M})+$ DTT $(100 \mu \mathrm{M})$, BF-1 $(10 \mu \mathrm{M})+\mathrm{Na}_{2} \mathrm{SeO}_{3}(100 \mu \mathrm{M})$, BF-1 $(10 \mu \mathrm{M})+\mathrm{Na}_{2} \mathrm{Se}(100 \mu \mathrm{M})$ in Tris-HCl buffer. Luciferase (final concentration, $2 \mu \mathrm{g} / \mathrm{mL})$ and ATP $(2 \mathrm{mM}, 50 \mu \mathrm{L})$ were added after the incubation for different times at $37^{\circ} \mathrm{C}$.

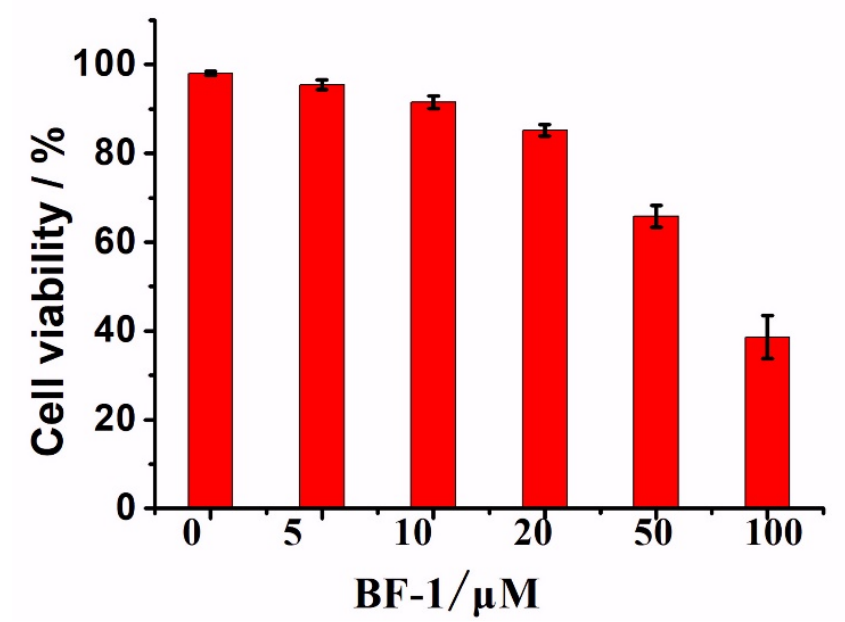

Figure S11. Cell viability of BF-1 $(0,5,10,20,50$ and $100 \mu \mathrm{M})$ at $24 \mathrm{~h}$ in MCF-7-luc cells. Data are presented as the mean $\pm \operatorname{SD}(n=3)$.

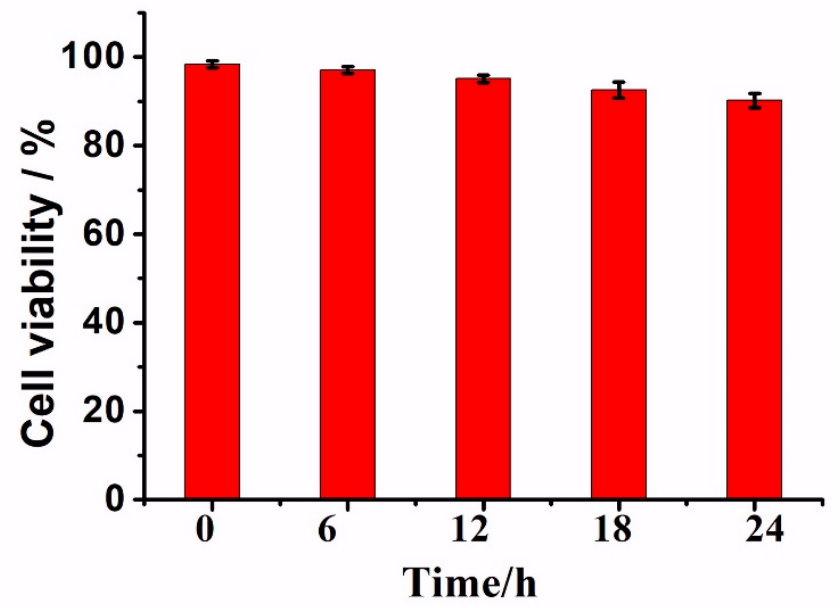

Figure S12. Cell viability of BF-1 $(10 \mu \mathrm{M})$ at different times $(0,6,12,18,24 \mathrm{~h})$ in MCF-7-luc cells. Data are presented as the mean $\pm \mathrm{SD}(\mathrm{n}=3)$. 


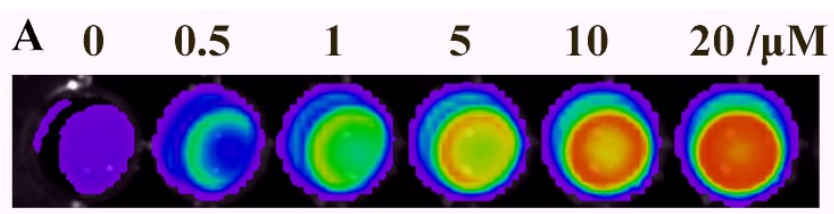

$\begin{array}{llllllllllll}0 & 0.4 & 0.8 & 1.2 & 1.6 & 2.0 & 2.4 & 2.8 & 3.2 & 3.6 & 4.0\end{array}$

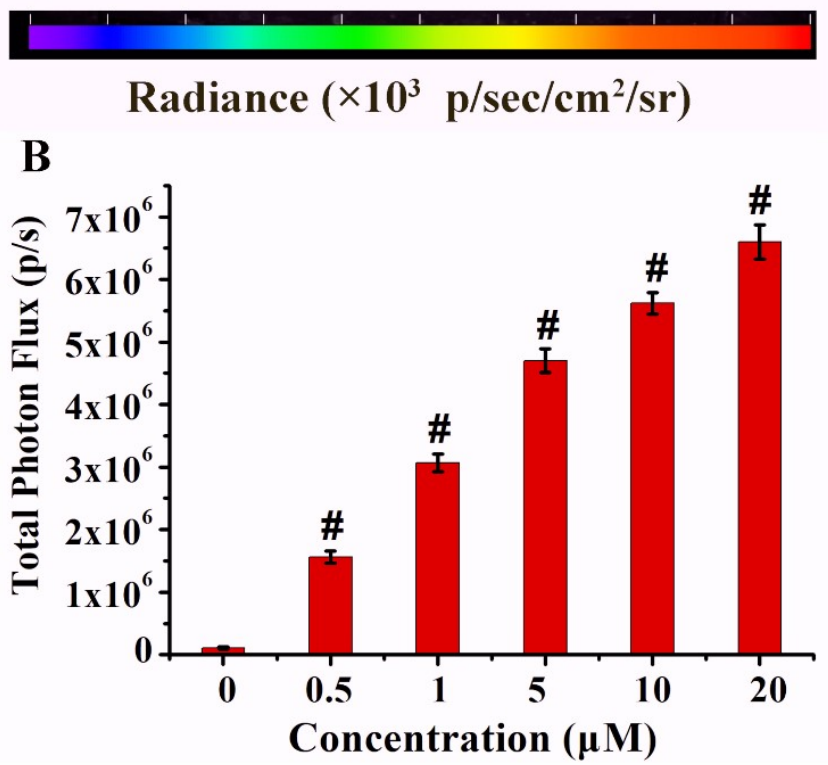

Figure S13. (A) Bioluminescence imaging of various concentrations of exogenous Sec in live MCF-7-luc cells using BF-1. The MCF-7-luc cells were pretreated with various concentrations of Sec $(0 \mu \mathrm{M}, 0.5 \mu \mathrm{M}, 1 \mu \mathrm{M}, 5 \mu \mathrm{M}, 10 \mu \mathrm{M}$, $20 \mu \mathrm{M})$ for $12 \mathrm{~h}$, and then incubated with BF-1 $(10 \mu \mathrm{M})$ for $30 \mathrm{~min}$. (B) Quantification of the total photon flux (photon/s) for the cells BL images. Data are presented as the mean $\pm \mathrm{SD}(\mathrm{n}=3) .{ }^{\sharp} P<0.001$ vs. control.
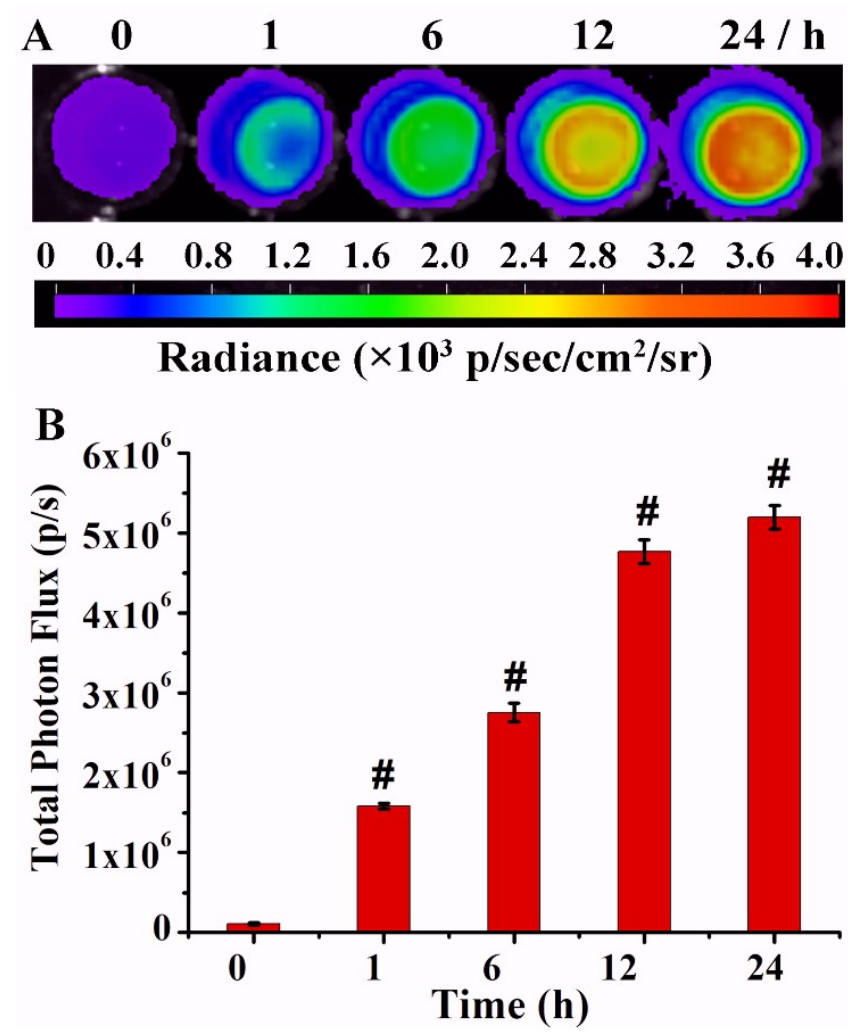

Figure S14. (A) Bioluminescence imaging of exogenous Sec at different times in live MCF-7-luc cells using BF-1. The MCF-7-luc cells were pretreated with Sec $(5 \mu \mathrm{M})$ for $0 \mathrm{~h}, 1 \mathrm{~h}, 6 \mathrm{~h}, 12 \mathrm{~h}, 24 \mathrm{~h}$, respectively, and then incubated with BF-1 $(10 \mu \mathrm{M})$ for 30 min. (B) Quantification of the total photon flux (photon/s) for the cells BL images. Data are 
presented as the mean $\pm \mathrm{SD}(\mathrm{n}=3) .{ }^{\#} P<0.001$ vs. control.

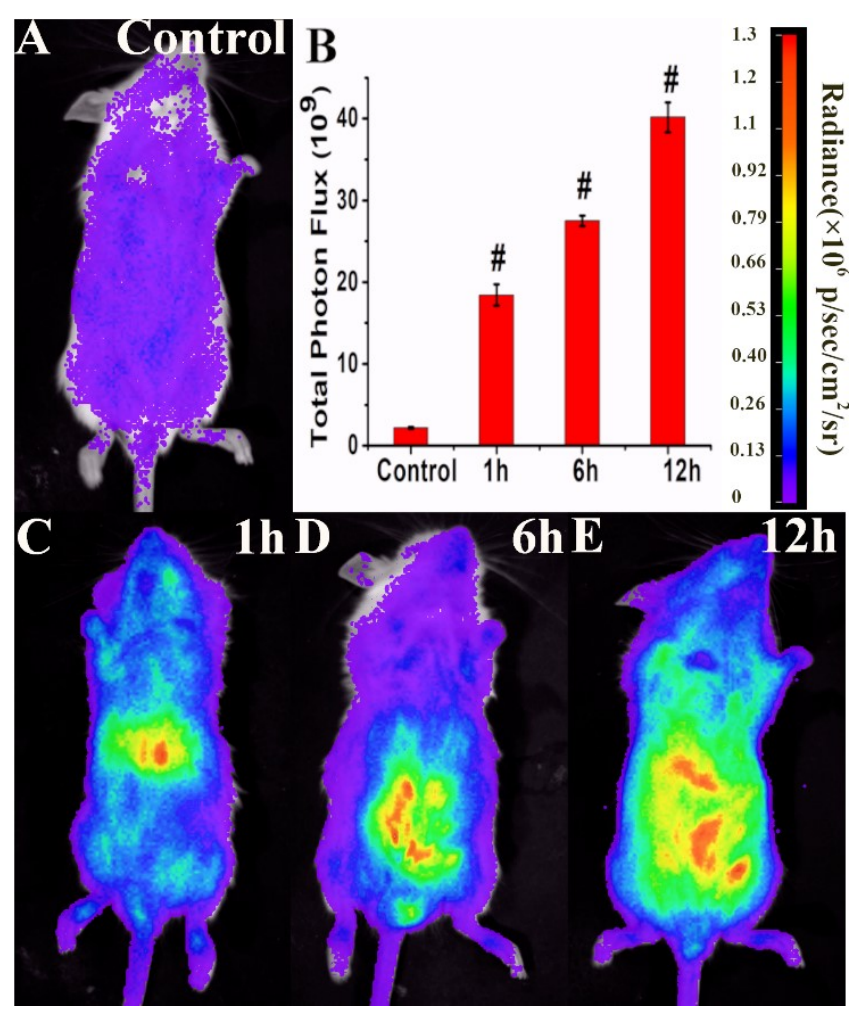

Figure S15. Representative bioluminescence images visualizing exogenous Sec in FVB-luc ${ }^{+}$mice using BF-1. Mice were i.p. injected with BF-1 (1.0 mM, $100 \mu \mathrm{L}$, DMSO: saline = 1: 9) as the control group (A). Quantification of the total photon flux ( $\mathrm{p} / \mathrm{sec} / \mathrm{cm}^{2} / \mathrm{sr}$ ) from the whole body area except tail. (B). Mice were i.p. injected with 5 equiv. (Sec) ${ }_{2}$ ( $5 \mathrm{mM}, 100 \mu \mathrm{L}$ saline), followed by i.p. injection of BF-1 (1.0 mM, $100 \mu \mathrm{L}$, DMSO: saline =1: 9) after $1 \mathrm{~h}(\mathrm{C}), 6 \mathrm{~h}$ (D), and $12 \mathrm{~h}$ (E). Images were taken after injection of BF-1 at $20 \mathrm{~min}$. Data are presented as the mean $\pm \mathrm{SD}(\mathrm{n}=3)$. ${ }^{\#} P<0.001$ vs. control.

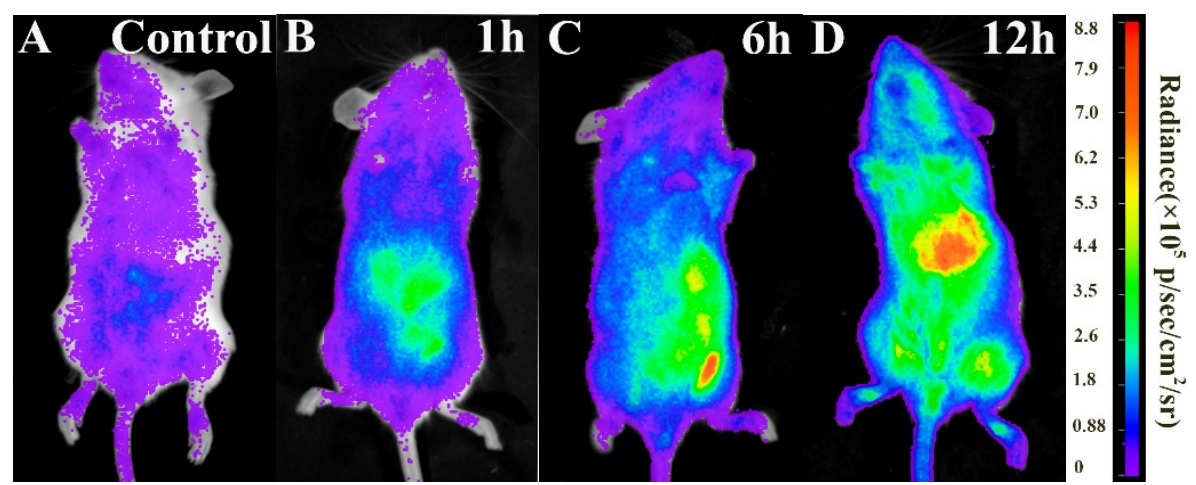

Figure S16. Representative bioluminescence images visualizing $\mathrm{Na}_{2} \mathrm{SeO}_{3}$-induced $\mathrm{Sec}$ in $\mathrm{FVB}$-luc ${ }^{+}$mice using BF-1. Mice were i.p. injected with BF-1 $(1.0 \mathrm{mM}, 100 \mu \mathrm{L}$, DMSO: saline =1: 9) as the control group (A). Mice were i.p. injected with 5 equiv. $\mathrm{Na}_{2} \mathrm{SeO}_{3}(5 \mathrm{mM}, 100 \mu \mathrm{L}$ saline), followed by i.p. injection of BF-1 $(1.0 \mathrm{mM}, 100 \mu \mathrm{L}$, DMSO: saline = 1: 9) after $1 \mathrm{~h}(\mathrm{~B}), 6 \mathrm{~h}(\mathrm{C})$, and $12 \mathrm{~h}(\mathrm{D})$. Images were taken after injection of BF-1 at $20 \mathrm{~min}$. 


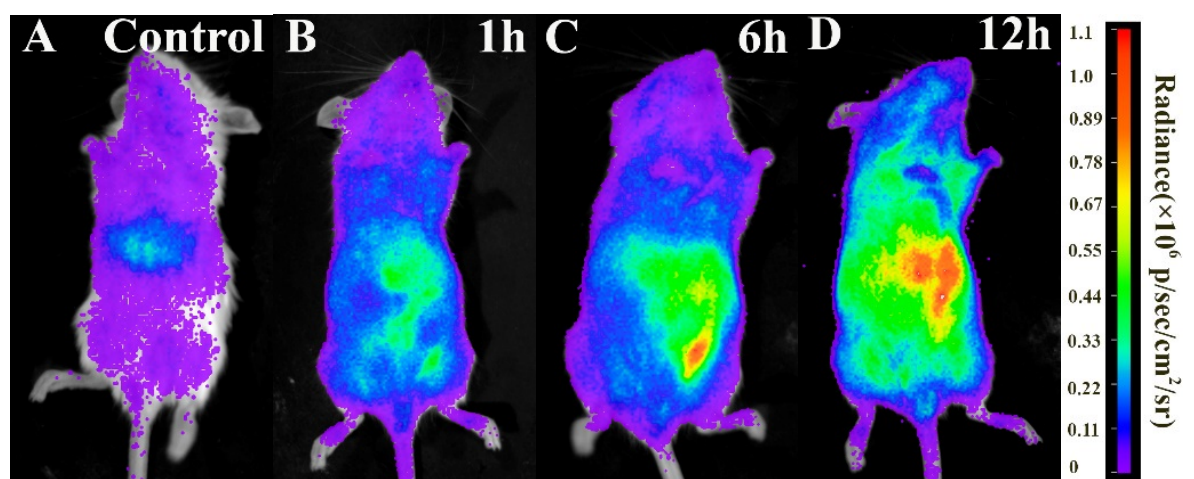

Figure S17. Representative bioluminescence images visualizing $\mathrm{Na}_{2} \mathrm{SeO}_{3}$-induced $\mathrm{Sec}$ in $\mathrm{FVB}$-luc ${ }^{+}$mice using BF-1. Mice were i.p. injected with BF-1 $(1.0 \mathrm{mM}, 100 \mu \mathrm{L}$, DMSO: saline =1: 9) as the control group (A). Mice were i.p. injected with 5 equiv. $\mathrm{Na}_{2} \mathrm{SeO}_{3}(5 \mathrm{mM}, 100 \mu \mathrm{L}$ saline), followed by i.p. injection of BF-1 $(1.0 \mathrm{mM}, 100 \mu \mathrm{L}$, DMSO: saline = 1: 9) after $1 \mathrm{~h}(\mathrm{~B}), 6 \mathrm{~h}(\mathrm{C})$, and $12 \mathrm{~h}(\mathrm{D})$. Images were taken after injection of BF-1 at $20 \mathrm{~min}$.

Table S1. Total Photon Flux of the FVB-luc ${ }^{+}$mice

\begin{tabular}{lcccc}
\hline & $\begin{array}{c}\text { Total Photon Flux } \\
\text { Control group } \times\left(\mathbf{1 0}^{\mathbf{9}}\right)\end{array}$ & $\begin{array}{c}\text { Total Photon Flux } \\
\text { in } \mathbf{1 h} \text { group } \times\left(\mathbf{1 0}^{\mathbf{9}}\right)\end{array}$ & $\begin{array}{c}\text { Total Photon Flux } \\
\text { in } \mathbf{6 h} \text { group } \times\left(\mathbf{1 0}^{\mathbf{9}}\right)\end{array}$ & $\begin{array}{c}\text { Total Photon Flux } \\
\text { in } \mathbf{1 2 h} \text { group } \times\left(\mathbf{1 0}^{\mathbf{9}}\right)\end{array}$ \\
\hline Mice in Figure 5 & 2.25 & 9.04 & 13.50 & 22.30 \\
Mice in Figure S16 & 2.32 & 8.80 & 14.00 & 24.40 \\
Mice in Figure S17 & 2.09 & 9.50 & 15.80 & 23.00 \\
mean \pm SD (n=3) & $2.22 \pm 0.12$ & $9.11 \pm 0.36$ & $14.43 \pm 1.21$ & $23.23 \pm 1.07$ \\
\hline
\end{tabular}

$0 \min 5 \min 10 \min 15 \min 20 \min 25 \min 30 \min 35 \min 40 \mathrm{~min} 50 \mathrm{~min} 60 \mathrm{~min}$

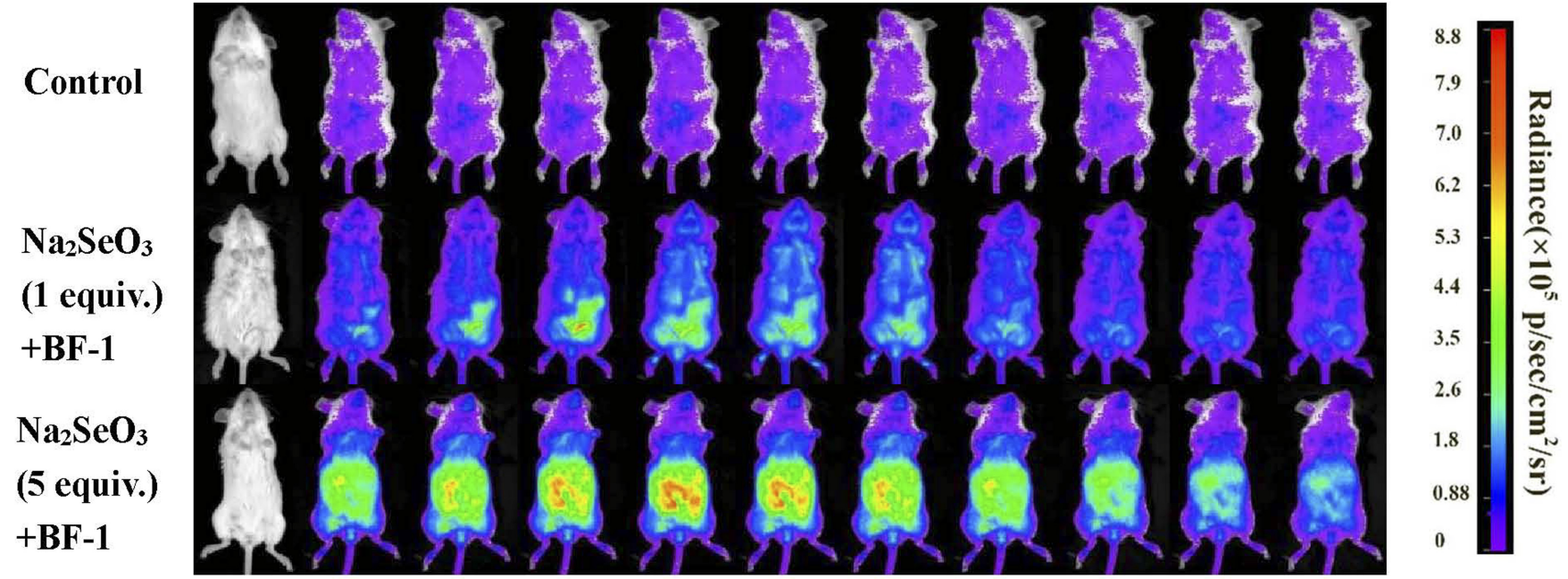

Figure S18. Time-course bioluminescence imaging of $\mathrm{Na}_{2} \mathrm{SeO}_{3}$-induced $\mathrm{Sec}$ in $\mathrm{FVB}$-luc ${ }^{+}$mice. Mice were i.p. injected with BF-1 (1.0 mM, $100 \mu \mathrm{L}$ DMSO: saline = 1: 9) as the control group (top row). Mice were i.p. injected with 1 equiv. $\mathrm{Na}_{2} \mathrm{SeO}_{3}(1 \mathrm{mM}, 100 \mu \mathrm{L}$ saline), followed by i.p. injection of BF-1 (1.0 mM, $100 \mu \mathrm{L}$ DMSO: saline $=1$ : 9) after $12 \mathrm{~h}$ (middle row). Mice were i.p. injected with 5 equiv. $\mathrm{Na}_{2} \mathrm{SeO}_{3}(5 \mathrm{mM}, 100 \mu \mathrm{L}$ saline), followed by i.p. injection of BF-1 (1.0 mM, $100 \mu \mathrm{L}$ DMSO: saline = 1: 9) after $12 \mathrm{~h}$ (bottom row). 


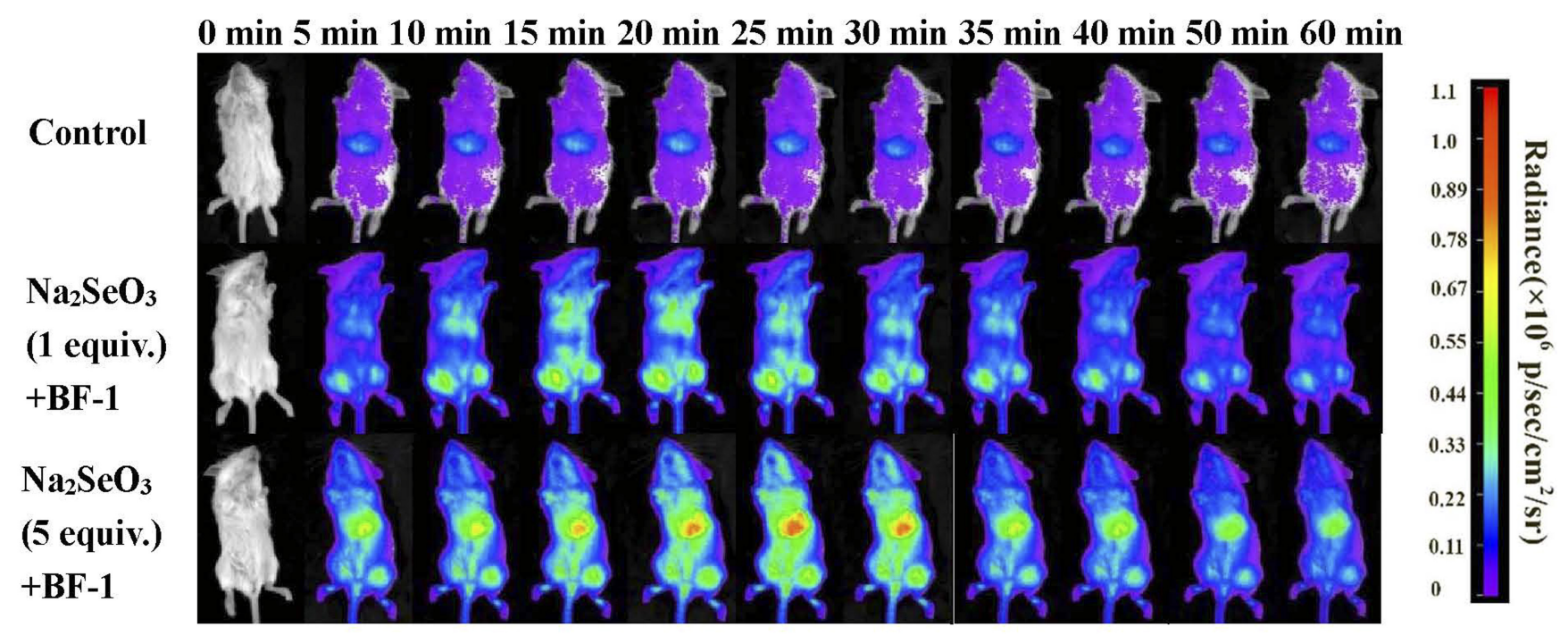

Figure S19. Time-course bioluminescence imaging of $\mathrm{Na}_{2} \mathrm{SeO}_{3}$-induced $\mathrm{Sec}$ in $\mathrm{FVB}-l u c^{+}$mice. Mice were i.p. injected with BF-1 (1.0 mM, $100 \mu \mathrm{L}$ DMSO: saline = 1: 9) as the control group (top row). Mice were i.p. injected with 1 equiv. $\mathrm{Na}_{2} \mathrm{SeO}_{3}(1 \mathrm{mM}, 100 \mu \mathrm{L}$ saline), followed by i.p. injection of BF-1 (1.0 mM, $100 \mu \mathrm{L}$ DMSO: saline = 1: 9) after $12 \mathrm{~h}$ (middle row). Mice were i.p. injected with 5 equiv. $\mathrm{Na}_{2} \mathrm{SeO}_{3}(5 \mathrm{mM}, 100 \mu \mathrm{L}$ saline), followed by i.p. injection of BF-1 (1.0 mM, $100 \mu \mathrm{L}$ DMSO: saline = 1: 9) after $12 \mathrm{~h}$ (bottom row).

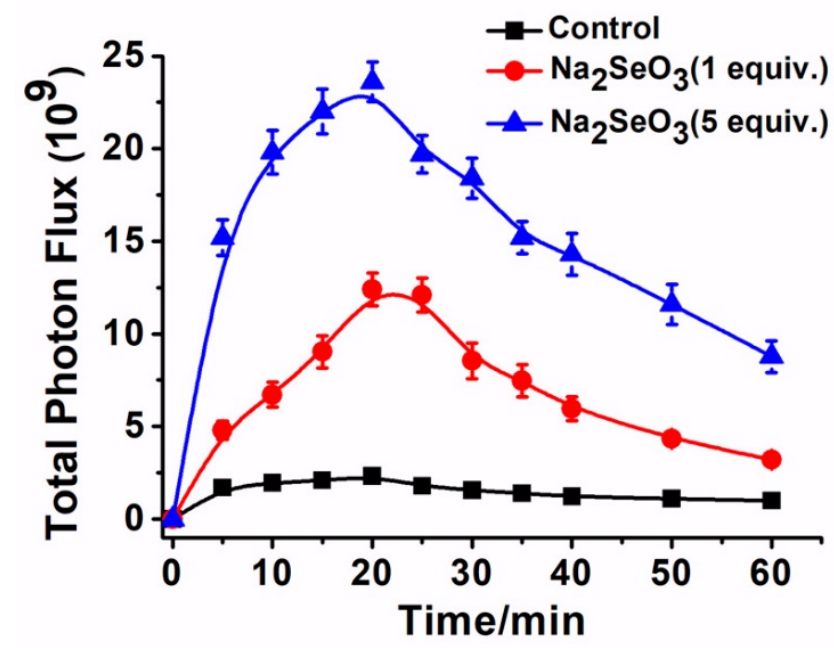

Figure S20. Quantification of the total photon flux $\left(\mathrm{p} / \mathrm{sec} / \mathrm{cm}^{2} / \mathrm{sr}\right)$ from the whole body area for the mice images in Figure $6, \mathrm{~S} 18, \mathrm{~S} 19$. Data are presented as the mean $\pm \mathrm{SD}(\mathrm{n}=3)$.

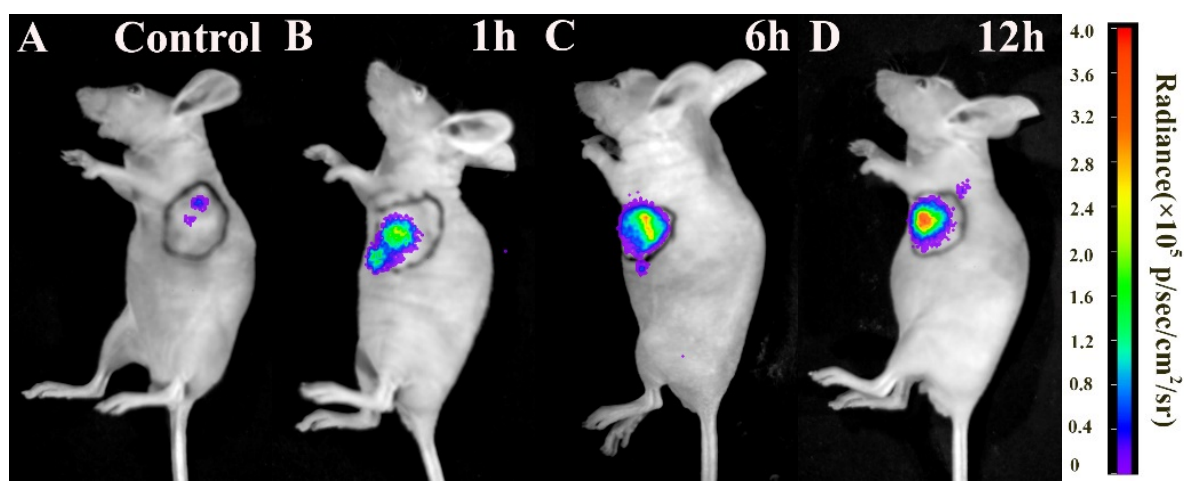

Figure S21. Representative bioluminescence images of BF-1 in tumor-bearing mice. Mice were intravenously injected with BF-1 (2 mM, $100 \mu \mathrm{L}$ saline, 3\% DMSO, 1\% Tween 80$)$ as the control group (A). Mice were 
intratumorally injected with $\mathrm{Na}_{2} \mathrm{SeO}_{3}(7 \mathrm{mM}, 100 \mu \mathrm{L}$ saline), followed by intravenous injection of BF-1 (2 mM, 100 $\mu \mathrm{L}$ saline, 3\% DMSO, 1\% Tween 80) after $1 \mathrm{~h}(\mathrm{~B}), 6 \mathrm{~h}(\mathrm{C})$, and $12 \mathrm{~h}(\mathrm{D})$.

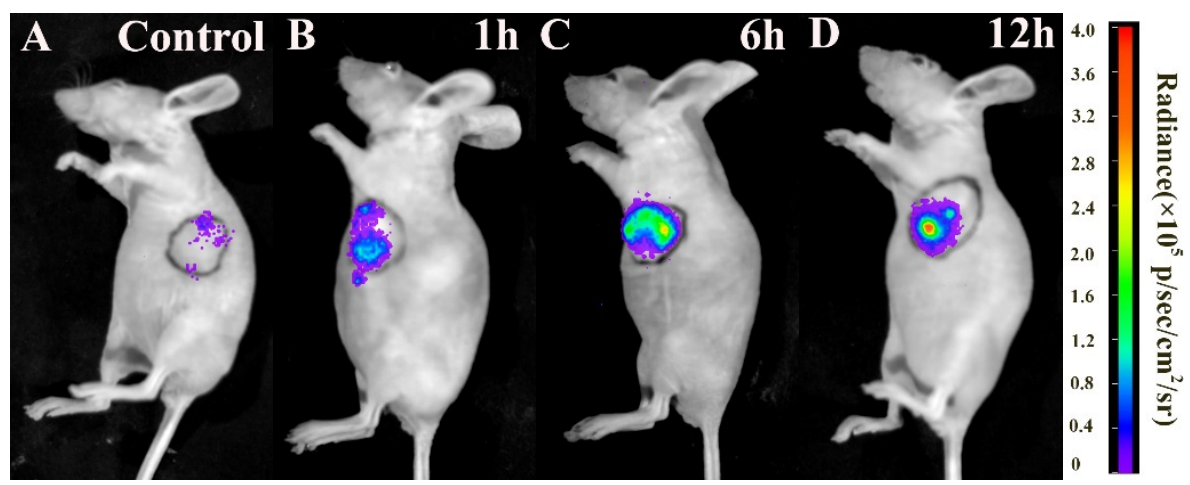

Figure S22. Representative bioluminescence images of BF-1 in tumor-bearing mice. Mice were intravenously injected with BF-1 (2 mM, $100 \mu \mathrm{L}$ saline, 3\% DMSO, 1\% Tween 80$)$ as the control group (A). Mice were intratumorally injected with $\mathrm{Na}_{2} \mathrm{SeO}_{3}(7 \mathrm{mM}, 100 \mu \mathrm{L}$ saline), followed by intravenous injection of BF-1 $(2 \mathrm{mM}, 100$ $\mu \mathrm{L}$ saline, 3\% DMSO, 1\% Tween 80) after $1 \mathrm{~h}(\mathrm{~B}), 6 \mathrm{~h}(\mathrm{C})$, and $12 \mathrm{~h}(\mathrm{D})$.

Table S2. Total Photon Flux of the nude mice

\begin{tabular}{lccccc}
\hline & $\begin{array}{l}\text { Total Photon Flux } \\
\text { in Control group } \times \\
\left(\mathbf{1 0}^{\mathbf{8}}\right)\end{array}$ & $\begin{array}{l}\text { Total Photon Flux } \\
\text { in } \mathbf{1 h} \text { group } \times\left(\mathbf{1 0}^{\mathbf{8}}\right)\end{array}$ & $\begin{array}{l}\text { Total Photon Flux } \\
\text { in } \mathbf{6 h} \text { group } \times\left(\mathbf{1 0}^{\mathbf{8}}\right)\end{array}$ & $\begin{array}{c}\text { Total Photon Flux } \\
\text { in 12h group } \times\left(\mathbf{1 0}^{\mathbf{8}}\right)\end{array}$ \\
\hline Mice in Figure 7 & 0.14 & 1.30 & 3.25 & 4.08 \\
Mice in Figure S21 & 0.16 & 1.45 & 3.38 & 4.48 \\
Mice in Figure S22 & 0.13 & 1.28 & 3.40 & 4.22 \\
mean \pm SD $(\mathrm{n}=3)$ & $0.15 \pm 0.01$ & $1.34 \pm 0.09$ & $3.34 \pm 0.08$ & $4.26 \pm 0.20$ \\
\hline
\end{tabular}

0 min 5 min $10 \min 15 \min 20 \min 25 \min 30 \mathrm{~min} 35 \mathrm{~min} 40 \mathrm{~min} 50 \mathrm{~min} 60 \mathrm{~min}$

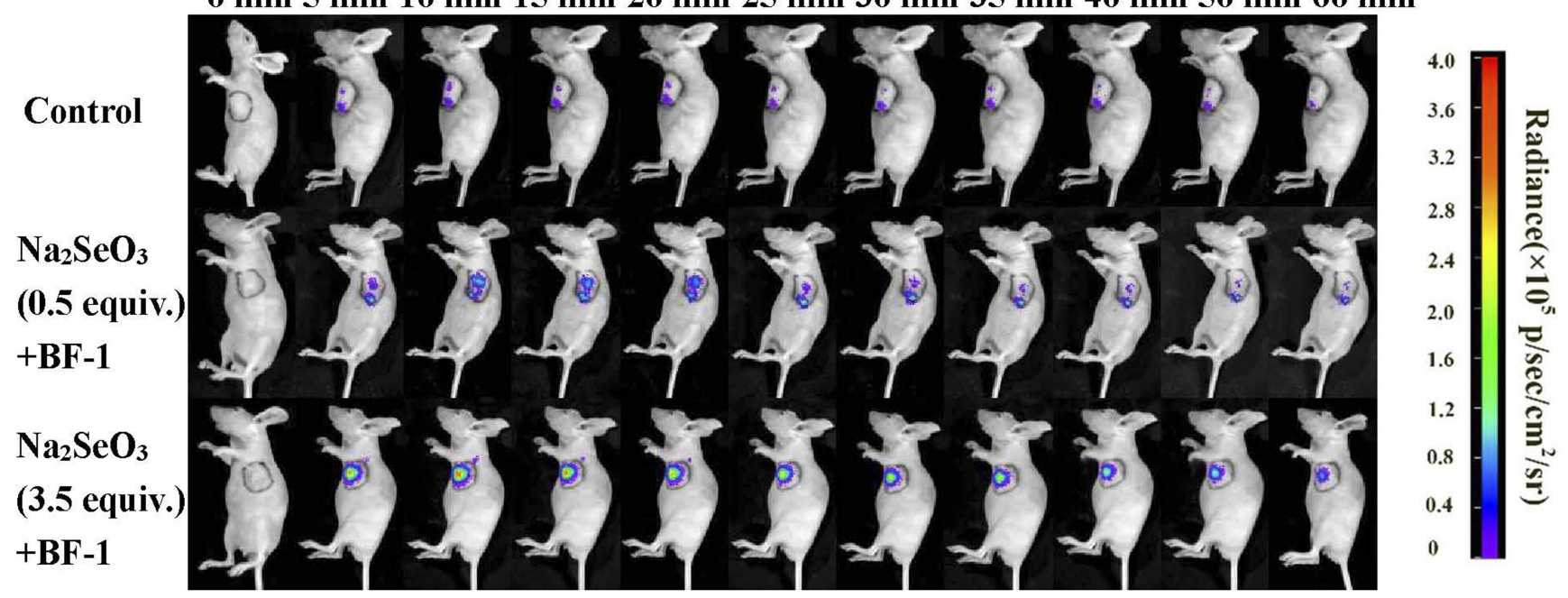

Figure S23. Time-course bioluminescence imaging of $\mathrm{Na}_{2} \mathrm{SeO}_{3}$-induced $\mathrm{Sec}$ in tumor-bearing mice. Mice were intravenously injected with BF-1 (2 mM, $100 \mu \mathrm{L}$ saline, 3\% DMSO, 1\% Tween 80$)$ as the control group (top row). Mice were intratumorally injected with 0.5 equiv. $\mathrm{Na}_{2} \mathrm{SeO}_{3}(1 \mathrm{mM}, 100 \mu \mathrm{L}$ saline), followed by intravenous injection of BF-1 ( $2 \mathrm{mM}, 100 \mu \mathrm{L}$ saline, 3\% DMSO, 1\% Tween 80 ) after $12 \mathrm{~h}$ (middle row). Mice were intratumorally injected with 3.5 equiv. $\mathrm{Na}_{2} \mathrm{SeO}_{3}(7 \mathrm{mM}, 100 \mu \mathrm{L}$ saline), followed by intravenous injection of $\mathrm{BF}-1$ ( $2 \mathrm{mM}, 100 \mu \mathrm{L}$ saline, $3 \%$ DMSO, $1 \%$ Tween 80 ) after $12 \mathrm{~h}$ (bottom row). 
$0 \min 5 \min 10 \min 15 \min 20 \min 25 \min 30 \min 35 \min 40 \mathrm{~min} 50 \mathrm{~min} 60 \mathrm{~min}$

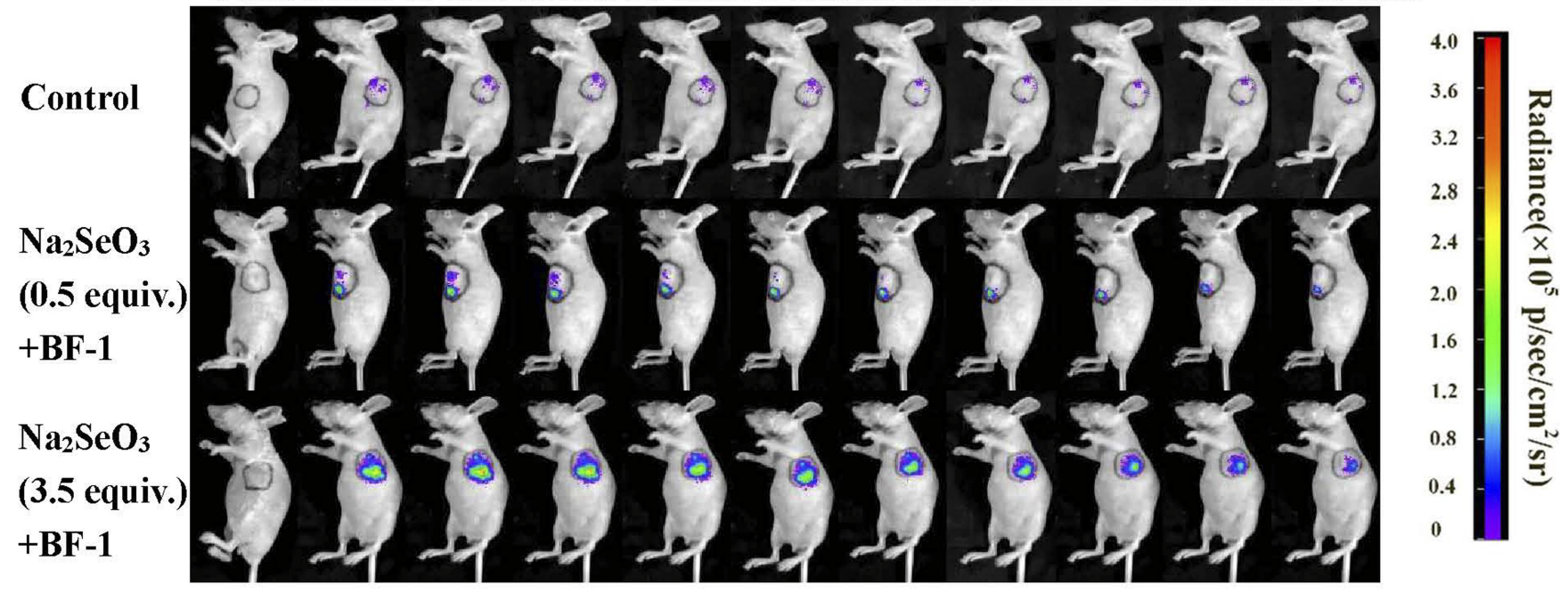

Figure S24. Time-course bioluminescence imaging of $\mathrm{Na}_{2} \mathrm{SeO}_{3}$-induced Sec in tumor-bearing mice. Mice were intravenously injected with BF-1 (2 mM, $100 \mu \mathrm{L}$ saline, 3\% DMSO, 1\% Tween 80 ) as the control group (top row). Mice were intratumorally injected with 0.5 equiv. $\mathrm{Na}_{2} \mathrm{SeO}_{3}(1 \mathrm{mM}, 100 \mu \mathrm{L}$ saline), followed by intravenous injection of BF-1 ( $2 \mathrm{mM}, 100 \mu \mathrm{L}$ saline, 3\% DMSO, 1\% Tween 80 ) after $12 \mathrm{~h}$ (middle row). Mice were intratumorally injected with 3.5 equiv. $\mathrm{Na}_{2} \mathrm{SeO}_{3}(7 \mathrm{mM}, 100 \mu \mathrm{L}$ saline), followed by intravenous injection of BF-1 ( $2 \mathrm{mM}, 100 \mu \mathrm{L}$ saline, $3 \%$ DMSO, $1 \%$ Tween 80 ) after $12 \mathrm{~h}$ (bottom row).

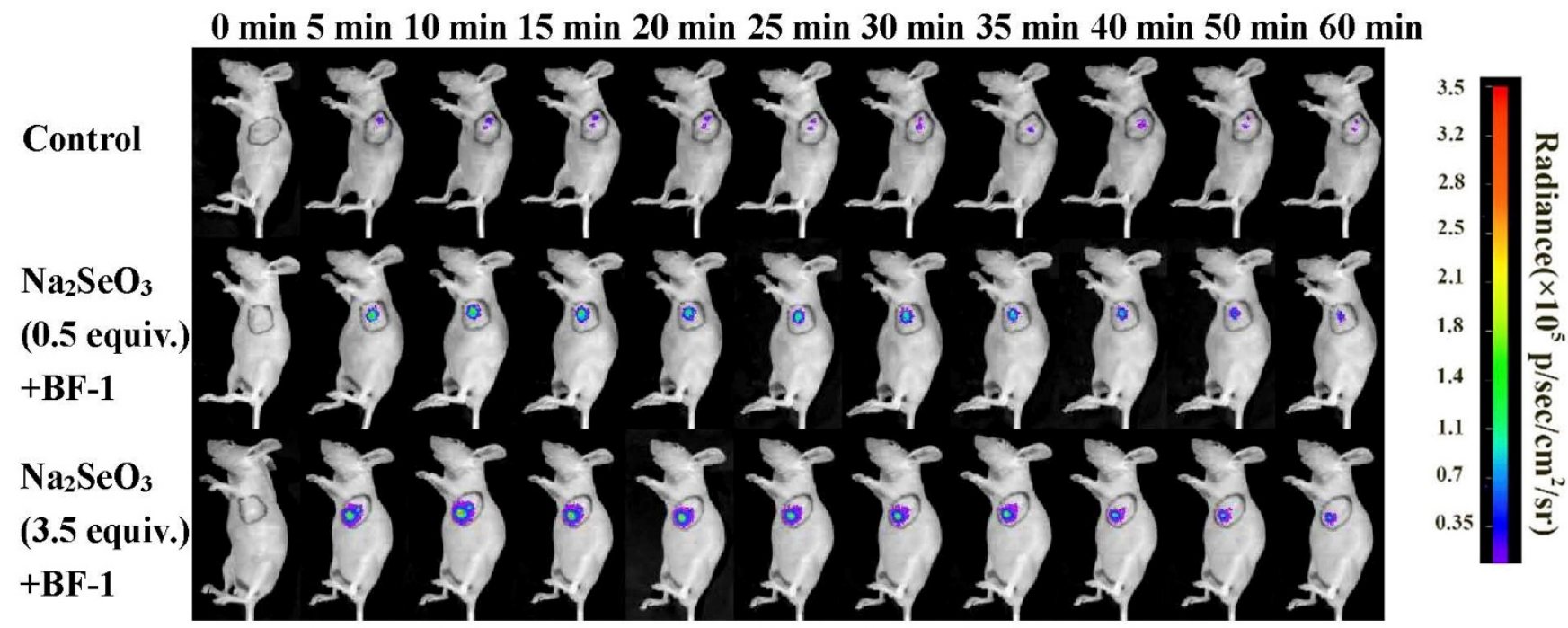

Figure S25. Time-course bioluminescence imaging of $\mathrm{Na}_{2} \mathrm{SeO}_{3}$-induced Sec in tumor-bearing mice. Mice were intravenously injected with BF-1 (2 mM, $100 \mu \mathrm{L}$ saline, 3\% DMSO, 1\% Tween 80$)$ as the control group (top row). Mice were intratumorally injected with 0.5 equiv. $\mathrm{Na}_{2} \mathrm{SeO}_{3}(1 \mathrm{mM}, 100 \mu \mathrm{L}$ saline), followed by intravenous injection of BF-1 (2 mM, $100 \mu \mathrm{L}$ saline, 3\% DMSO, 1\% Tween 80) after $12 \mathrm{~h}$ (middle row). Mice were intratumorally injected with 3.5 equiv. $\mathrm{Na}_{2} \mathrm{SeO}_{3}(7 \mathrm{mM}, 100 \mu \mathrm{L}$ saline), followed by intravenous injection of BF-1 ( $2 \mathrm{mM}, 100 \mu \mathrm{L}$ saline, $3 \%$ DMSO, $1 \%$ Tween 80 ) after $12 \mathrm{~h}$ (bottom row). 


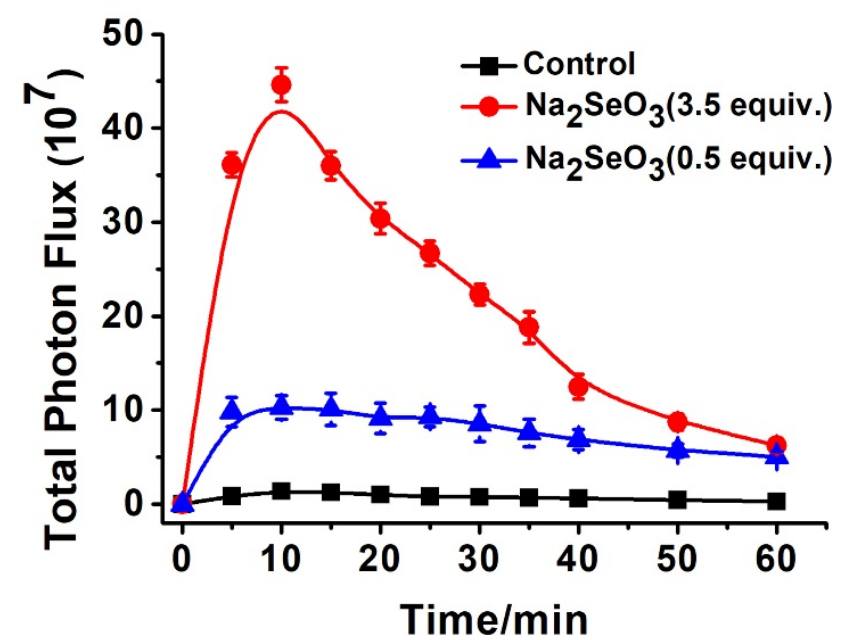

Figure S26. Quantification of the total photon flux $\left(\mathrm{p} / \mathrm{sec} / \mathrm{cm}^{2} / \mathrm{sr}\right)$ from the tumor area for the mice images in Figure $\mathrm{S} 23, \mathrm{~S} 24, \mathrm{~S} 25$. Data are presented as the mean $\pm \mathrm{SD}(\mathrm{n}=3)$. 
Table S3. Summary of previous reported Sec probes

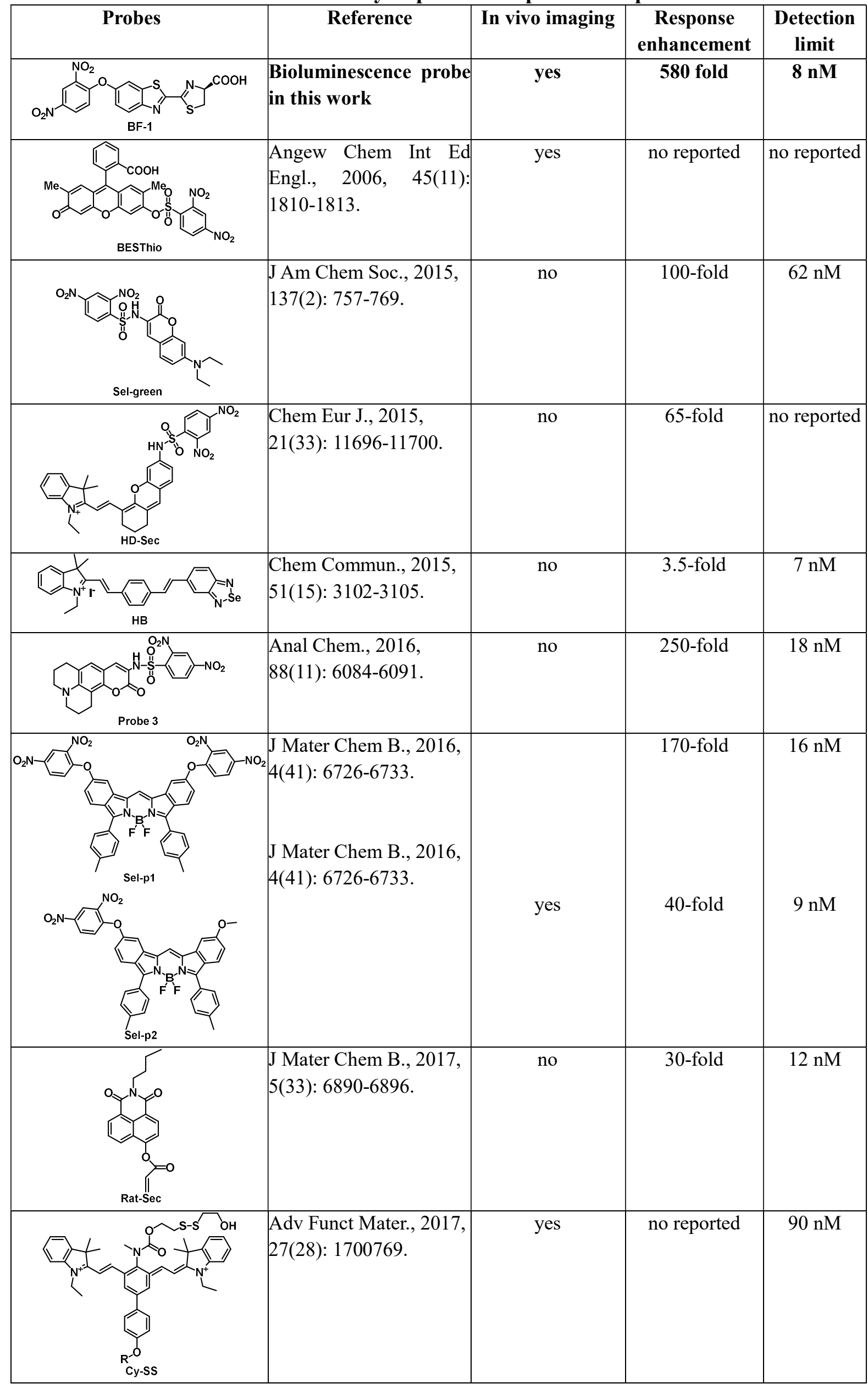




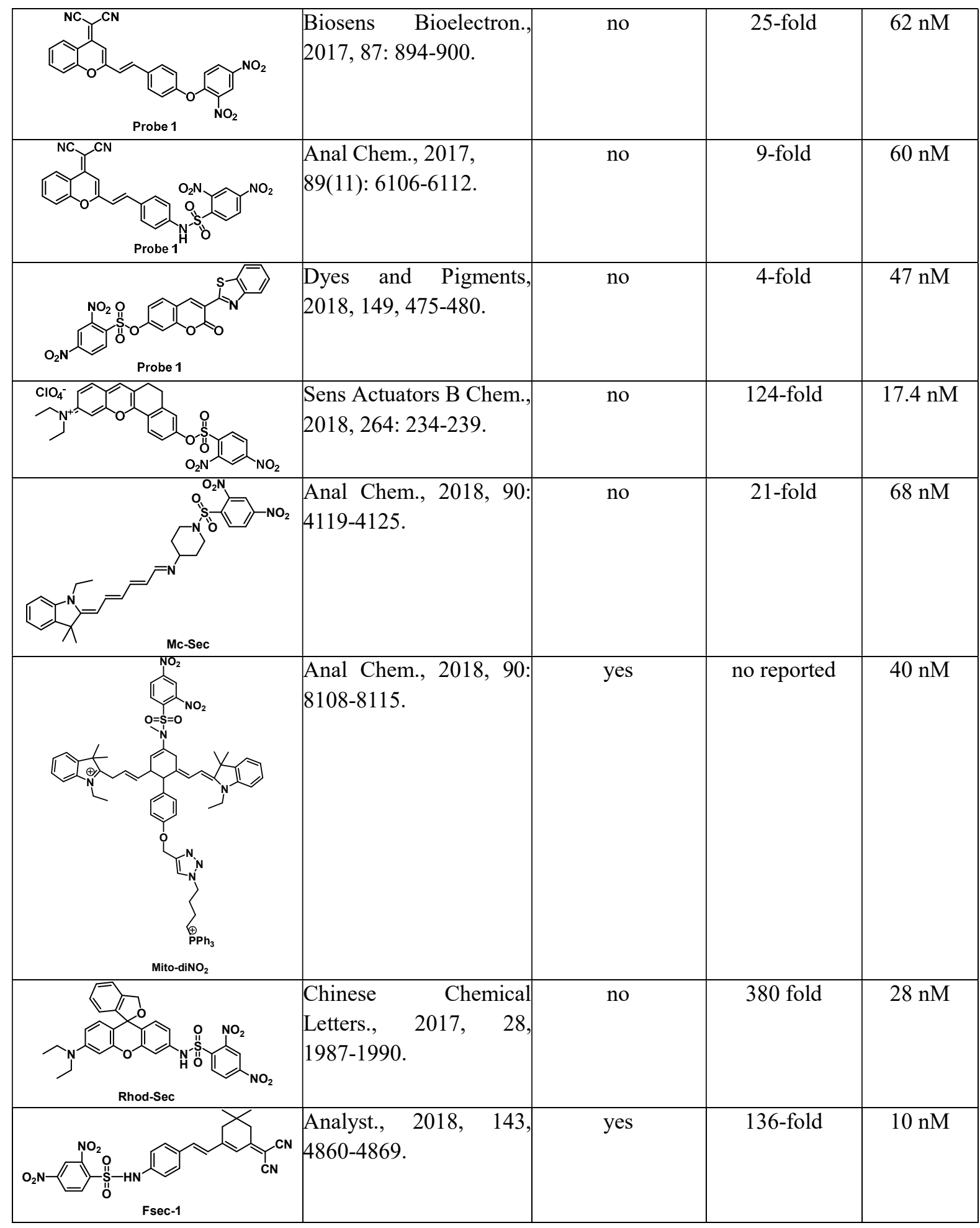




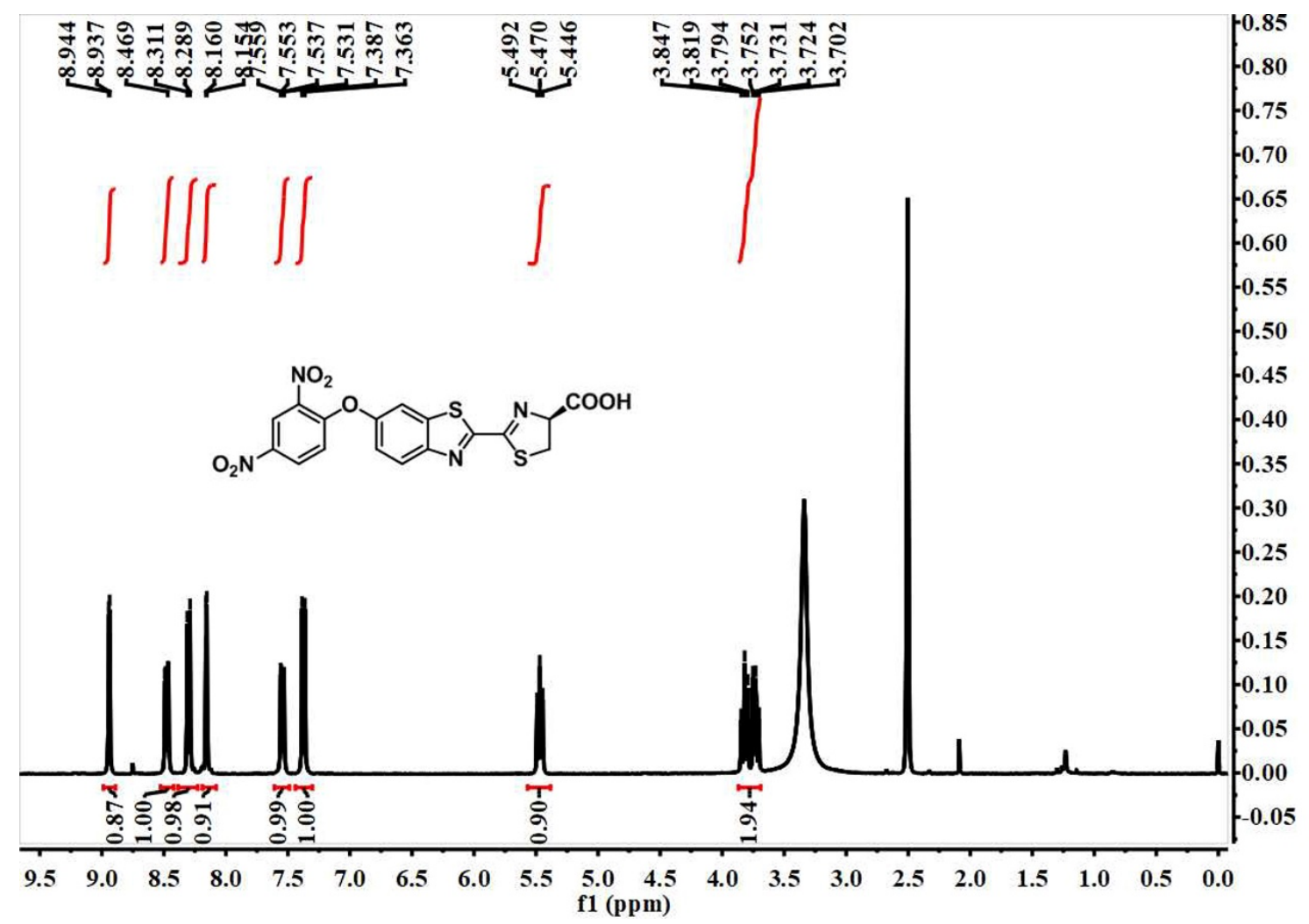

Figure S27. ${ }^{1} \mathrm{H}$ NMR spectra of BF-1.

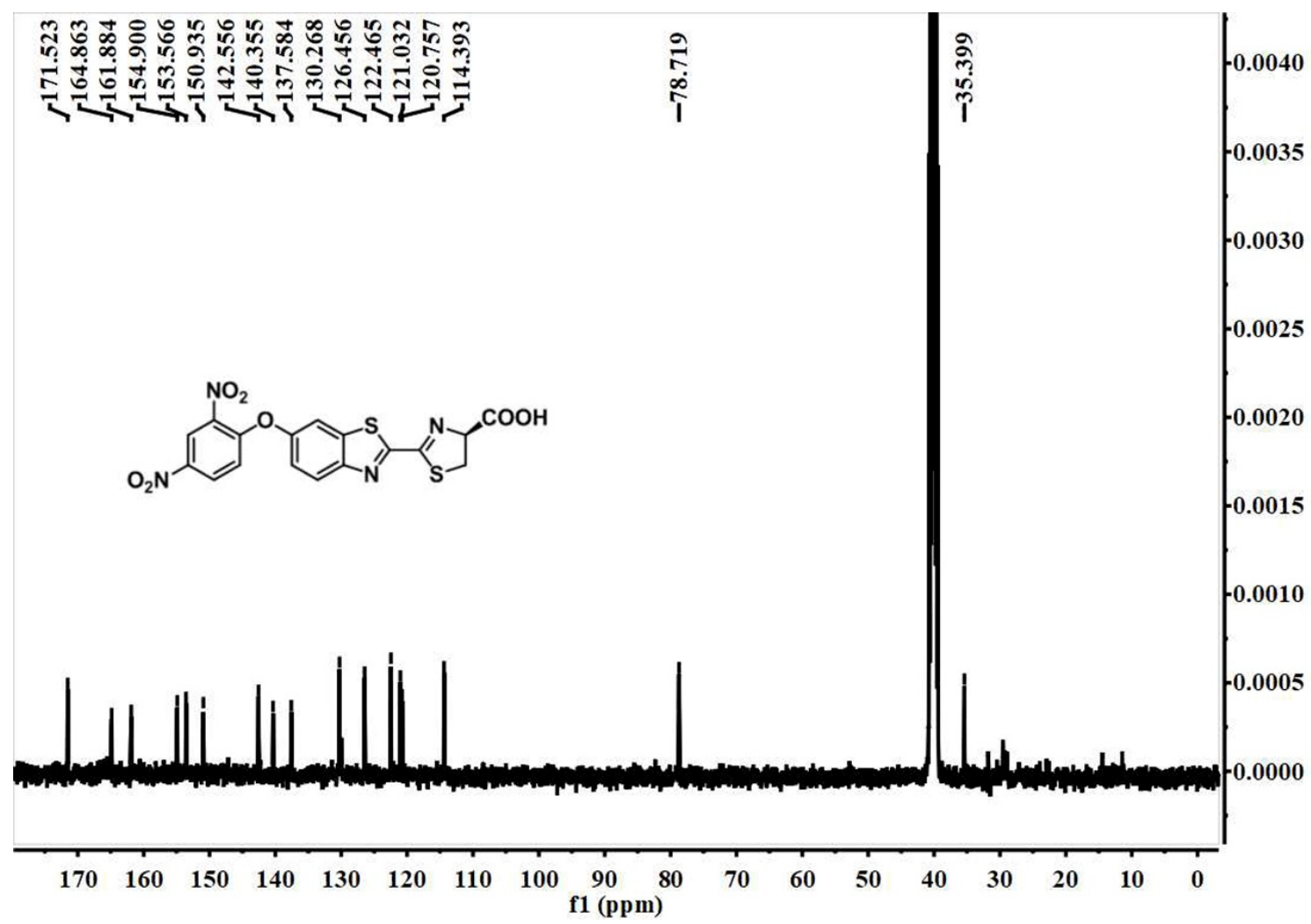

Figure S28. ${ }^{13} \mathrm{C}$ NMR spectra of BF-1. 


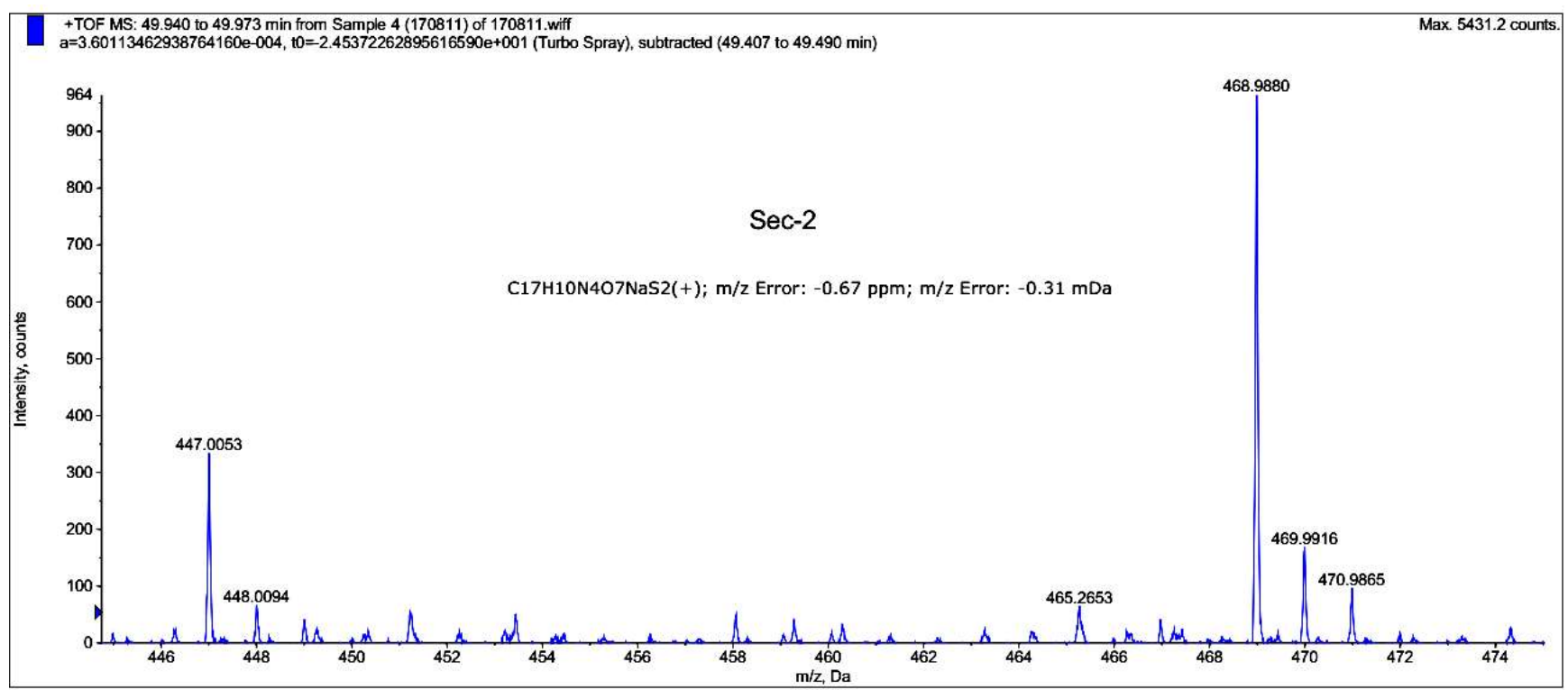

Figure S29. HRMS identification of BF-1. $(\mathrm{M}+\mathrm{Na})^{+}$calcd. for $\mathrm{C}_{17} \mathrm{H}_{10} \mathrm{~N}_{4} \mathrm{O}_{7} \mathrm{NaS}_{2}, 468.9888$; found, 468.9880 .

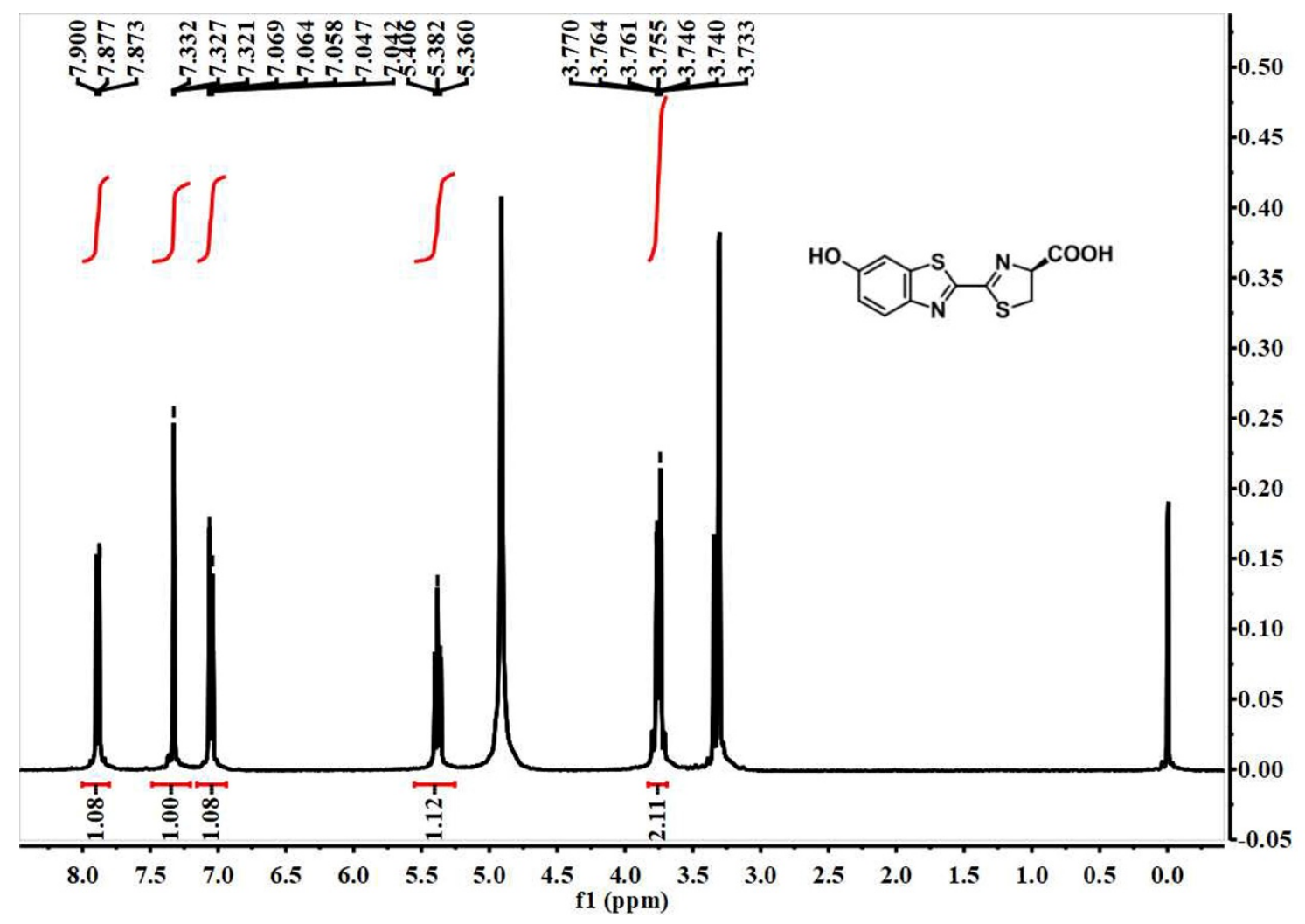

Figure S30. ${ }^{1} \mathrm{H}$ NMR spectra of D-luciferin. 


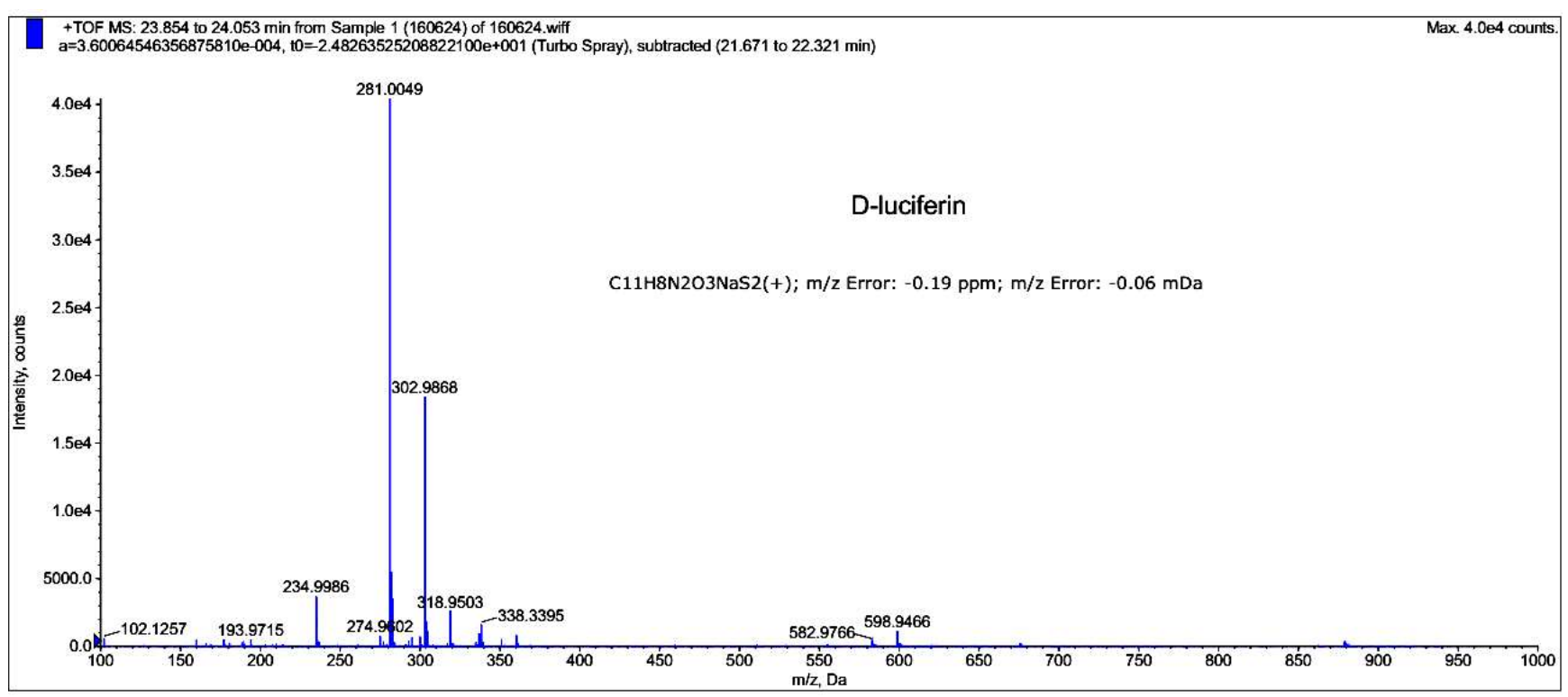

Figure S31. HRMS identification of D-luciferin. HRMS (ESI $)$ : $(\mathrm{M}+\mathrm{H})^{+}$calcd. for $\mathrm{C}_{11} \mathrm{H}_{9} \mathrm{~N}_{2} \mathrm{O}_{3} \mathrm{~S}_{2}, 281.0054$; found, 281.0049. (M+Na) $)^{+}$calcd. for $\mathrm{C}_{11} \mathrm{H}_{8} \mathrm{~N}_{2} \mathrm{O}_{3} \mathrm{NaS}_{2}, 302.9874$; found, 302.9868 .

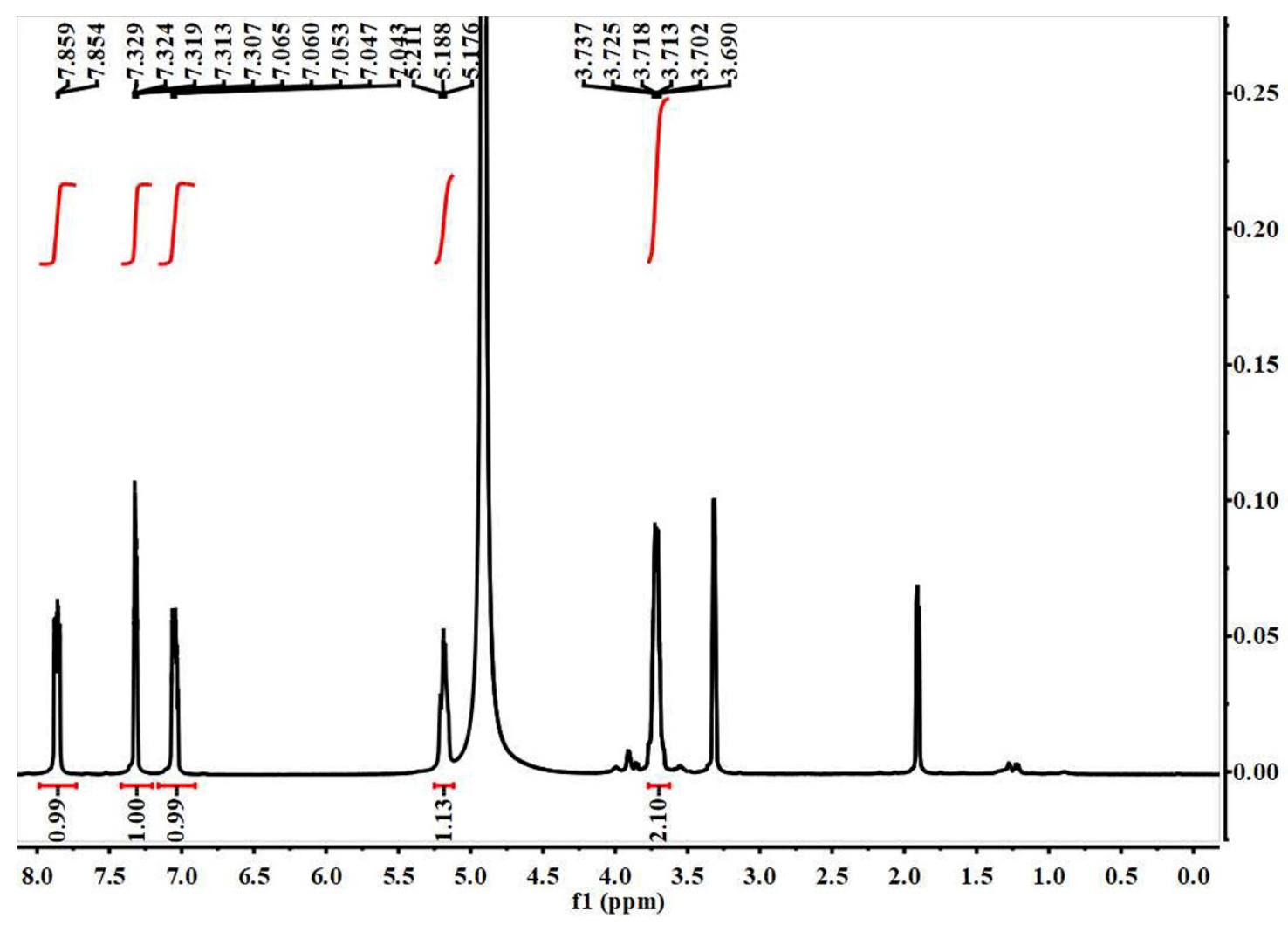

Figure S32. ${ }^{1} \mathrm{H}$ NMR spectra of the isolated product of BF-1 + Sec. 


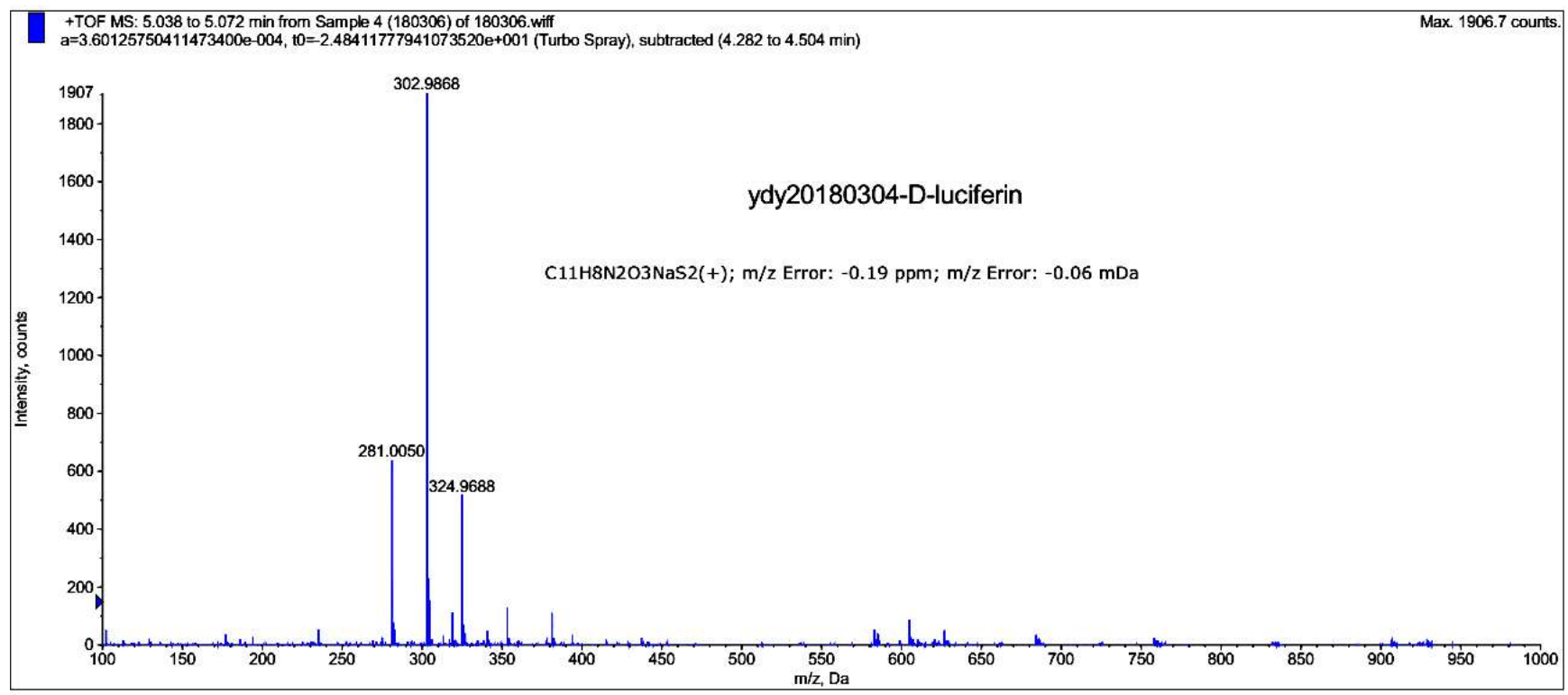

Figure S33. HRMS spectra of the isolated product of BF-1 + Sec. HRMS $\left(\mathrm{ESI}^{+}\right)$: $(\mathrm{M}+\mathrm{H})^{+}$calcd. for $\mathrm{C}_{11} \mathrm{H}_{9} \mathrm{~N}_{2} \mathrm{O}_{3} \mathrm{~S}_{2}$, 281.0054; found, 281.0050. (M+Na) calcd. for $\mathrm{C}_{11} \mathrm{H}_{8} \mathrm{~N}_{2} \mathrm{O}_{3} \mathrm{NaS}_{2}$, 302.9874; found, 302.9868 . 